NBER WORKING PAPER SERIES

THE U.S. EMPLOYMENT-POPULATION REVERSAL IN THE 2000S:

FACTS AND EXPLANATIONS

\author{
Robert A. Moffitt \\ Working Paper 18520 \\ http://www.nber.org/papers/w18520 \\ NATIONAL BUREAU OF ECONOMIC RESEARCH \\ 1050 Massachusetts Avenue \\ Cambridge, MA 02138 \\ November 2012
}

This paper was prepared for the Brookings Panel on Economic Activity, Washington, DC, September 13-14, 2012 and was financially supported by the Brookings Institution. Comments from David Autor, Steven Davis, Alexandre Mas, the editors, and the conference participants are appreciated. Nicole Lott and $\mathrm{Lu} \mathrm{Xu}$ provided excellent research assistance. The views expressed herein are those of the author and do not necessarily reflect the views of the National Bureau of Economic Research.

NBER working papers are circulated for discussion and comment purposes. They have not been peerreviewed or been subject to the review by the NBER Board of Directors that accompanies official NBER publications.

(C) 2012 by Robert A. Moffitt. All rights reserved. Short sections of text, not to exceed two paragraphs, may be quoted without explicit permission provided that full credit, including $\odot$ notice, is given to the source. 
The U.S. Employment-Population Reversal in the 2000s: Facts and Explanations

Robert A. Moffitt

NBER Working Paper No. 18520

November 2012

JEL No. J2,J22

\begin{abstract}
$\underline{\text { ABSTRACT }}$
The decline in the employment-population ratios for men and women over the period 2000-2007 prior to the Great Recession represents an historic turnaround in the evolution of U.S. employment. The decline is disproportionately concentrated among the less educated and younger groups within the male and female populations and, for women, disproportionately concentrated among the unmarried and those without children. About half of men's decline can be explained by declines in wage rates and by changes in nonlabor income and family structure influences, but the decline among women is more difficult to explain and requires distinguishing between married and unmarried women and those with and without children, who have each experienced quite different wage and employment trends. Neither taxes nor transfers appear likely to explain the employment declines, with the possible exception of the Supplemental Nutrition Assistance Program. Other influences such as the minimum wage or health factors do not appear to play a role, but increases in incarceration could have contributed to the decline among men.
\end{abstract}

Robert A. Moffitt

Department of Economics

Johns Hopkins University

3400 North Charles Street

Baltimore, MD 21218

and NBER

moffitt@jhu.edu 
There are many indicators of trends and cycles in the labor market. The unemployment rate is the primary indicator used during cycles but, for long-term trends, the employmentpopulation ratio is the best indicator of trends in the quantity of labor supplied. From peak to peak, when the unemployment rate is held fixed, the employment-population ratio necessarily reflects the labor force participation rate, which is the common measure of labor supply. Longterm trends in the employment-population ratio can therefore also be taken as reflecting trends in labor supply.

This study examines the decline in the employment-population ratio from 2000 to 2007, just before the Great Recession began. The ratio stood at 74.1 percent in 2000 and at 71.8 percent in 2007 for the population 16-64. The decline was greater among younger and less educated men and women. This drop in the ratio represents an historic reversal from its upward trend over the prior 30 years and hence constitutes a major change in the U.S. labor market.

The employment-population ratio has been much discussed recently in the press and among researchers and policy-makers because of its sharp decline during the Great Recession. The ratio fell from 72 percent in 2007 to 66 percent in 2011 for the population 16-64, a tremendous decline by historical standards. ${ }^{1}$ Many have noted the slow rate of recovery of this ratio after the official trough of the Recession in June 2009, when it stood at 67 percent. In fact, the ratio continued to decline for several months thereafter, bottoming out only in December,

${ }^{1}$ Many public discussions cite figures including the population 65 and over. For this larger population, the ratio fell from 63 to 58 percent over the same period. 
2009. Since that time, it has risen only slightly. Behind this trend is a decline in the labor force participation rate, constituting a contribution to the decline in the unemployment rate but not a particularly welcome one.

The decline in the employment-population ratio prior to the Recession may be part of the reason for its slow recovery. Indeed, Stock and Watson (2012) predict that, if the long-term downward trend in the ratio were to continue, future recessions are likely to be deeper and will have slower recoveries. More immediately, if the long-term decline continues, we may not see the employment-population ratio return to its 2007 value even when the recovery is judged to be complete.

There has been very little formal study of this reversal. In a session at the American Economic Association meetings in January, 2012, Henry Farber found that changes in the agegender-education composition of the population could explain no more than a quarter of the decline, and Robert Shimer noted the greater rate of decline among youth and speculated that rigid wages or intertemporal substitution between the pre-2000 and post-2000 periods could be partly responsible. $^{2} \quad$ Autor (2010) found that changes in the employment-to-population ratio over the 1979-2007 period as well as the subperiod after 2000 are positively correlated with changes in wages, suggesting a conventional labor supply explanation for the trend. Macunovich (2010) found a significant decline in female labor supply from 1999-2001 to 20072009, particularly among unmarried women without children, but also found that conventional observables (wage rates, numbers of children, etc.) could explain very little of the change over time. Aaronson et al. (2009) examined the aggregate labor force participation rate through 2005, 
finding that demographic, cyclical, and structural factors probably contributed to the recent downturn in that rate.

Trends in the labor supply of women have been extensively studied. The recent literature in this area has noted that, while female labor supply has historically exhibited strong growth, that growth slowed in the 1990s, prompting some observers to ask whether it has plateaued (Goldin, 2006). Discussions of the slowdown have mainly focused on whether wage elasticities of labor supply and other coefficients in female labor supply equations have changed over time and are responsible. Blau and Kahn (2007) found that the wage elasticity for married women declined noticeably from the 1980s to the 1990s, bringing their wage elasticities closer to those of men. More relevant to the post-2000 period are studies by Bishop et al. (2009), Heim (2007), and Macunovich (2010), who examined whether wage elasticities were falling after 2000, with some studies going through 2002, others through 2003, and one through 2007-2009. Those ending in 2002 or 2003 found falling wage elasticities while the study ending in 2007-2009 found a slight increase. A problem with these studies is that the ending years were all at a different point in the business cycle than the beginning years, complicating the inferences to be drawn. More relevant for present purposes, the question to be pursued here is whether trends in one aspect of labor supply—-the employment-population ratio—can be explained by changes in observed variables rather than changes in coefficients. ${ }^{3}$

2 http://www.aeaweb.org/webcasts/2012/index.php

3 As noted above, Macunovich (2010) found that little of the change for women through 2007-2009 could be explained by observables. Hotchkiss (2006), using a model without wages in the labor supply equation, likewise found that observables could explain little of the change in female labor force participation through 2005. 
Another strand of the literature for women has focused on a so-called "opt-out" revolution among well-educated and professional married women, whose labor force participation rates fell in the 2000s (Walls et al., 2010). The speculation in this line of argument is that more-educated women are increasingly deciding to stay at home to engage in child-rearing rather than engage in market work. There has been some research on this hypothesis but very little focuses on the 2000-2007 period and very little of that attempts to search specifically for variables and causes of the decline (Antecol (2010), Bousey (2008), Macunovich (2010) ). Goldin (2006) notes that we may have to wait for several years to see if recent cohorts of more educated women exhibit opt-out patterns over the remainder of their life cycle.

Here I conduct an analysis of the decline in the employment-population ratio through 2007 with two parts. First, I describe the patterns of decline in the employment-to-population ratio in detail, examining the patterns by time period as well as by demographic group--age, gender, education, race, and other characteristics. This analysis reveals that the decline is disproportionately concentrated among the young and less educated, both for men and women. For women, the decline is particularly strong among unmarried women without children. Second, I conduct an investigation for proximate causes of the decline. About half of the decline of the male employment-population ratio can be explained by declines in wage rates and changes in nonlabor income and family structure influences. However, the factors responsible for the decline in female employment are more difficult to explain and require separate examination of wage and employment trends for married and unmarried women and for those with and without children, each of whom exhibit different patterns of employment and wage change. I also find that neither taxes nor transfers appear likely to explain the employment declines, with the 
possible exception of the Supplemental Nutrition Assistance Program, nor do other influences such as the minimum wage or health factors.

\section{Trends and Patterns}

The Bureau of Labor Statistics publishes statistics on the employment-population ratio drawn from the monthly interviews of the Current Population Survey, asking employment status during the week preceding the interview of all individuals 16 and over. The middle line in Figure 1 shows the trend for the civilian noninstitutional population 16-64 from 1970 to 2011 (those over 64 will not be examined in this study). The trend in the ratio was positive, with intermittent cyclical variation, from 1970 to about 1999 or 2000 . At that point it reversed course and began the decline which is the object of interest here. The ratio declined from 74.1 percent to 71.8 percent between 2000 and 2007, over two-and-a-half percentage points. ${ }^{4}$ It plummeted further thereafter as the Great Recession began. The departure from the historical trend is dramatic and clear from the figure.

The trend in the overall ratio masks quite different trends by gender, as shown in the Figure. The ratio for men declined, on average, between 1970 and 1983, after which it remained stable until 2000, before beginning a decline after that. Its decline from 2000 to 2007 was 2.7 percentage points. However, for women, the employment-population ratio secularly increased from 1970 to 2000, consistent with the well-known trend growth of female employment in the

${ }^{4}$ These figures differ from those published by the BLS for the whole population, which includes those 65 and over. The employment-population ratio for the elderly increased over the 
U.S. over this period. After 2000, it stopped growing and declined slightly, falling by 1.7 percentage points by 2007. The decline was therefore smaller in magnitude for women than for men, but their deviation from pre-2000 trend was greater.

The focus of this study will be on the period 2000-2007 as compared to the preceding period of the 1990s and will investigate causes of the reversal of the trend in the employmentpopulation ratio from the first period to the second. An immediate issue in conducting such an investigation is whether to attempt to explain both the trend and the cycles in the ratio, for it is clear from Figure 1 that the ratio behaves procyclically. Here, the focus will be restricted to an investigation of the trend and not the cycle, at least to the greatest extent possible. To this end, I shall select years where the economy was roughly at the same point in the cycle-in fact, as closely as possible to a peak. Figure 2 shows the unemployment rate along with the trend in the overall employment-population ratio we have already seen in Figure 1. The unemployment rate in 2007 stood at 4.60 percent in March 2007 and was closest to this rate in March 1999 (4.61 percent). ${ }^{5}$ Therefore, I shall focus on the change in the ratio between those points in time, which exhibit the same magnitude of declines as those discussed above for 2000 to 2007 (2.7 percentage points for men and 1.7 percentage points for women). For the period of the late 1980s and the 1990s, the lowest March unemployment rate was recorded in 1989, when it stood at 5.41 percent (it was even higher for all prior years in the 1980s). This is slightly higher than it

period.

${ }^{5}$ These figures differ slightly from BLS figures for the 16-64 population because they are computed on the sample used for model estimation below, which has some exclusions. Also, it might be noted that the estimates of the natural rate of unemployment constructed by the Congressional Budget Office were exactly the same in all four quarters of 1999 and 2007 (U.S. Congressional Budget Office, 2012). 
was in March 1999. Nevertheless, the period from March 1989 to March 1999 will be taken as illustrating the trend over the "1990s." Over that period, the employment-population ratio for men fell by a small 0.9 percentage points and that of women rose by 3.6 percentage points. ${ }^{6}$

Movements in the employment-population ratio can be a result of shifts in the demographic composition of the population as well as shifts in the employment-population ratio for groups of the population with the same characteristics. While composition is likely to be more important over longer periods of time than 8 years, it could also be of some importance over the 1989-2007 period and could affect the interpretation of the trends in the aggregate ratio I have thus far shown. To this end, I use the March Current Population Survey (CPS) in each of the years 1989 to 2007, which collected information on the employment and labor force status of all individuals 16 and over as well as their age, level of education, race, and gender. Classifying the population into four age groups (16-24, 25-39, 40-54, and 55-64), four education groups (less than high school, high school graduates, some college, college degree or more), and three race groups (White, Black, and Other), allows a determination of how the proportions of the population in the resulting 48 demographic groups for each gender affected their aggregate employment-population ratio trends with a standard shift-share decomposition. ${ }^{7}$ As can be seen

\footnotetext{
${ }^{6}$ I should refer again, at this point, to some of the studies mentioned in the Introduction which studied labor supply trends through 2002, 2003, or even 2005. Clearly the unemployment rate was much higher, and the employment-population ratio much lower, in those years but partly for cyclical reasons. As noted before, this makes it difficult to make inferences about trends from those studies.

${ }^{7}$ The decomposition used is $\mathrm{y}_{\mathrm{t}+1}-\mathrm{y}_{\mathrm{t}}=\sum_{\mathrm{g}} \mathrm{p}_{\mathrm{gt}}\left(\mathrm{y}_{\mathrm{g}, \mathrm{t}+1}-\mathrm{y}_{\mathrm{gt}}\right)+\sum_{\mathrm{g}}\left(\mathrm{p}_{\mathrm{g}, \mathrm{t}+1}-\mathrm{p}_{\mathrm{gt}}\right) \mathrm{yg}_{\mathrm{g}, \mathrm{t}+1}$, where $\mathrm{y}_{\mathrm{gt}}$ is the employment-population ratio for group $g$ in year $t$, $\mathrm{pgt}_{\mathrm{gt}}$ is the proportion of the population in group $g$ in year $t$, and the groups $g=1, \ldots, 48$ are the demographic groups. A decomposition using 
in Figure 3, which plots both the actual ratio, and the ratio holding composition constant at its 1999 value, only small fractions of the changes in the ratios were a result of changes in composition. There was only a slight compositional change for men during the 2000s downturn and only a small change for women from 1989 to 1999.

With it established that most of the decline in the employment-population ratio from 1999 to 2007 was not a result of changes in composition, the March CPS can now be used to describe the patterns of the decline in the ratio by demographic characteristic. The upper panels of Tables 1(a) and 1(b) show the patterns of change from 1999 to 2007 by age, education, and gender, using the same four categories of age and education used for the composition exercise. ${ }^{8}$ There is a great deal of variance in the magnitudes of the changes across the cells, but some patterns can be detected. Reading down the columns, it appears that the largest employmentpopulation declines occurred, with some exceptions, among those less than 40 years old, with the decline more monotonic for women than for men. Among those less than 40, the declines were usually sharper for those less than 25. Reading across the rows, there is also a correlation with education levels, with declines generally larger for those with high school degrees or less than among those with at least some college. The combination of being younger and less educated generally result in the largest declines (e.g., over 4 percentage points). On the other hand, declines in the ratio, even if smaller in magnitude, often occurred for those 40-54 and for those with college degrees or more, particularly for women in the latter case (perhaps consistent with

weights in the other years yields results that are almost identical.

${ }^{8}$ Standard errors are very small and not shown. The sample size per cell is never less than 400 and ranges up to 7500 , with most sizes in the 1500-to-4000 range. 
the “opt-out” revolution). Thus the decline did not occur exclusively among the young and less educated. $^{9}$

The patterns for 1989-1999 are different, as should be expected. For men, there were generally declines in the ratio but most were smaller in magnitude than for the later 1999-2007 period and there was a slight tendency for the magnitude of the difference to be greater for the younger and less educated. For women, the contrast is greater, with almost all categories showing positive trends in the ratio. The difference in trends is particularly strong for those younger and less educated.

Comparisons by race (Appendix Table A-1) show roughly the same patterns of decline for White, Black, and Other Race groups. The magnitudes vary considerably across the racial groups, although smaller sample sizes for some categories may play a role. Some of the largest declines occurred among Black men and women, but for many age-education groups, they were smaller than for White men and women than for Blacks.

For the very young, it is possible that some of the declines in employment could simply reflect increases in school attendance. The CPS asks young individuals (16-24) who report they are not employed if they are attending school. Table 2 shows that there were increases in school attendance from 1999 to 2007 for men with a high school degree or less and for all women. However, with only a couple of exceptions, the increases were smaller than those that had occurred during the 1989-1999 period.

${ }^{9}$ Separate tabulations by full-time and part-time status show that essentially all of the decline for men was from full-time work to no work, whereas the decline for women was roughly equally split between declines from full-time and part-time work. 
Some of the papers in the literature referenced in the Introduction note the importance of marital status to labor supply trends, especially those of women, and the analysis below will also find major differences with respect to marital status. For men, the employment-population ratio declined over the 1999-2007 period by 1.6 percentage points for married men but that for unmarried men was almost double, 2.9 percentage points. For women, the contrast was even greater, with the ratio declining by only one-third of a percentage point for married women but by 2.9 percentage points for those unmarried. Thus the majority of the declines were among the unmarried, not the married.

Table 3 shows the patterns of decline by marital status by age-education category. From 1999 to 2007, married men's employment-population ratios still declined more for the youngest (16-24) and less educated groups but the ratios for unmarried men declined more for older less educated men. For women, while the relatively greater concentration of declines in the younger and less educated groups occurred for those of both marital statuses, the magnitudes of the declines for those groups were almost always considerably greater for unmarried women. An additional indication in the data (not shown in the tables) is that the greater declines for unmarried women are concentrated among those without children, for whom the ratio declined by 3.5 percentage points between 1999 to 2007, compared to a decline of only four-tenths of a percentage point among unmarried women with children. ${ }^{10}$ Unmarried women without children constitute about one-third of all women 16-64. 


\section{Labor Supply Models and Evidence}

The workhorse model in labor economics for explaining changes in individual employment and hours of work has been the static labor supply model, enshrined in textbooks. In that model, individuals choose whether to work at all, and how many hours to work, as a function of the market wage rate they face and the amount of nonlabor income available to them. The theoretical effect of the market wage rate on hours of work is ambiguous in sign but is unambiguously positive for the decision to work at all, while the prediction for the effect of nonlabor income on both hours and the decision to work is negative.

The empirical literature on the model is vast. Killingsworth (1983) exhaustively reviewed the literature from the 1960s and 1970s while Blundell and MaCurdy (1999) and Meghir and Phillips (2010) have conducted updated reviews. Unfortunately, the bulk of this literature focuses on hours of work and not on the employment decision. For hours of work, the conventional wisdom from this literature is that wage elasticities are zero or negative for primeage men and significantly positive for women, and that income elasticities are negative for both but greater in magnitude for women, but often not very large for either. The conclusions for men have been challenged over the years (e.g., Juhn et al., 1991) and, most recently, by Keane (2011) and Keane and Rogerson (2012). The latter argued explicitly that wage elasticities for the employment decision (the "extensive margin”) are likely larger than those for the hours decision (the “intensive margin”), and are very important for the aggregate labor supply elasticity (see also Rogerson and Wallenius (2009)). For women, it has long been recognized that the

10 Again, Macunovich (2010) found this same result. 
extensive margin is particularly important, going back to early labor supply work that separated it from the intensive margin (Mroz, 1987). Meghir and Phillips (2010) also examine wage elasticities for participation and find them to be larger for women than for men, albeit not that large even for women. Aside from the estimation of wage elasticities of participation, it is also well known that the time-series increase in labor supply of women has been particularly strong on the extensive margin.

Another literature of relevance is the literature on separating demand from supply influences on trends in wage differentials among men and women in the U.S. (Katz and Autor, 1999; Acemoglu and Autor, 2011). While this literature is rarely referenced in the labor supply literature, its main focus on the correlation between wage changes and “quantity” changes--most often measured by total hours of work in a skill group--has implications for wage elasticities of labor supply. The main conclusion from that literature is that the last four or five decades have seen a trend-like expansion of the relative demand for more skilled workers and that, with the exception of the 1970s, relative supply has shifted outward only modestly--or has even shifted backward. This conclusion is based upon the general finding of a positive correlation of wage changes with hours changes across education and experience groups, implying a positive wage elasticity of labor supply, even for men. A recent paper focusing just on the employmentpopulation ratio within the same framework (Autor, 2010) reaches the same conclusions for that ratio, finding a positive correlation between changes in wages and the employment-population ratio over the period 1979-2007 and also over the period of the 2000s.

The empirical literature on the standard labor supply has reached many other general conclusions as well. For married women, it has been established that the influence of the level of 
her spouse's earnings is an important factor in her labor supply decision. The presence of young children, which tends to depress labor supply of women, is important as well as marital status, with unmarried women tending to work more than those who are married. For men, marital status is also correlated with labor supply (at least hours of work), with married men working longer than unmarried men. The presence of young children is generally found to have less impact, if any, on the labor supply decisions of men than for women.

A related but important literature focuses on the impact of tax and transfer programs on labor supply. The early literature on the effect of taxes was covered by Killingsworth (1983) and the later literature, by the reviews of Blundell and MaCurdy (1999) and Meghir and Phillips (2010). All of these studies concluded, to varying degrees, that tax responses were consistent with the literature on labor supply in general, namely, very modest responses for prime-age men and somewhat larger responses for women. ${ }^{11}$ This view has been challenged recently by Keane (2011), who argues that properly specified life cycle models with returns to human capital incorporated into the model imply larger wage elasticities. As for transfer programs, there is a similarly large literature focusing on different programs. The review of the early literature by Moffitt (1992) found rather significant responses of single-mother labor supply to the Aid to Families with Dependent Children (AFDC) program, and research on later reforms of that program show even larger responses (Grogger and Karoly, 2005). But Moffitt found very small effects of most other means-tested transfer programs, and a recent, newer review is consistent

${ }^{11}$ A related literature is that examining tax effects on taxable income. See the original contribution by Feldstein (1995), the recent review by Saez et al. (2012), and the recent contribution of Romer and Romer (2012). Moffitt and Wilhelm (2000) apply the methodological framework initially developed by Feldstein to hours of work. 
with this view (Ben-Shalom et al., forthcoming). There is less consensus in the literature on the effects of social insurance programs, where very divergent estimates of the effects on work incentives of the Social Security Retirement program, the Disability Insurance program, and Unemployment Insurance (UI) appear. The effects of UI have figured prominently in the discussion of the Great Recession but not as much in the discussion of labor supply trends prior to that.

\section{Labor Supply Influences Without Taxes and Transfers}

The approach taken here is to first examine the traditional determinants of labor supply appearing in the literature-wages and nonlabor income, but supplemented with demographic determinants (marital status, children, etc.)-- and to determine whether they can explain the reversal of the trend in the employment-population ratio from 1999 to 2007 relative to 19891999, including the patterns by age-education subgroup identified above. Taxes and transfers are considered subsequently. The primary data source for the analysis is again the March CPS data from 1989, 1999, and 2007, which are random samples of approximately 145,000, 132,000 and 206,000 individuals in each of the respective years. The household interviews collected information on all individuals 16 and over, from which I select only those between the ages of 16 and 64. In addition to information in the survey week on employment status, which is used to construct a dichotomous variable for whether an individual is employed, and demographic characteristics, information was collected on earnings and weeks of work in the calendar year 
prior to the interview week as well as on all forms of nonlabor income and other labor income received by members of the family in the same prior year. ${ }^{12}$

The modeling approach is kept as simple as possible to increase transparency. Observations on individuals from the 1989, 1999 and 2007 surveys are pooled into one data set and ordinary least squares (OLS) regressions for employment-status are estimated as function of wages, nonlabor income, and demographic variables (probit is also tested). Whether changes in those variables can explain the changes in the employment-population ratio from 1989 to 1999, and from 1999-2007, is the question then addressed. The capability of changes in the variables to explain changes in the ratio will be gauged not only for aggregate changes but for the pattern of age-education changes shown in Table 1. All equations are estimated separately by gender.

A difference between the study here and much of the recent work on female labor supply referenced in the Introduction is that the coefficients in the employment-status regression are held fixed for all three years and hence are not allowed to change with year. In the past literature, often separate equations are estimated by year, and then the change in labor supply (more often hours of work than employment status, however) from one time to the next is decomposed into the portion that can be explained by changes in the variables in the regression and the portion that is explained by the rest—changes in the coefficients on the variables and in the intercept. Here, because the focus is only on the former portion, constant coefficients are imposed.

12 Following most of the literature, individuals in group quarters and those with zero weights are excluded. All analyses are weighted. The number of observations in the male sample, pooled over all three years, is approximately 120 thousand; that for females is approximately 129 thousand. 
The equation estimated on the three years for each gender can be written as follows:

$$
E_{i t}=V_{i t} \gamma+X_{i} \beta+\varepsilon_{i t}
$$

where $E_{i t}$ is a dummy variable equal to 1 if individual $i$ in year $t(t=1989,1999$ or 2007) was employed and 0 if not; $V_{\text {it }}$ is a vector of variables which change over time and whose explanatory power is being assessed (wages, nonlabor income, family structure); $\mathrm{X}_{\mathrm{i}}$ is a vector of ageeducation-race dummy variables treated as fixed effects; and $\varepsilon_{\mathrm{it}}$ is an error term. The predicted change in the employment-population ratio between years $t$ and $t+1$ is therefore $\left[V_{t+1}\left(X_{i}=x\right)-V_{t}\right.$ $\left.\left(\mathrm{X}_{\mathrm{i}}=\mathrm{x}\right)\right] \gamma$ for age-education-race group $\mathrm{x}$, and the predicted change for the population as a whole is the weighted sum of these changes over all age-education-race groups. This fixed effect model is equivalent to a first-differenced model, although estimated on individual data rather than grouped data. The predictions can be compared to actual changes in the employmentpopulation ratio by group and overall.

$\underline{\text { Wages. }}$ The CPS interview asks respondents to report earnings in the past year as well as weeks worked in that year, plus average hours of work per week in that prior year. The third of these variables is particularly prone to measurement error and leads to the well-known problem of “division bias”, so I use weekly wages by dividing earnings by weeks worked. ${ }^{13}$ While the main results use weekly wages of all workers, I also test the results if only wages of

13 The division bias problem is presumably less important here because hours of work are not used as the dependent variable. Nevertheless, measurement error in hours work could be correlated with the error term in the employment equation. I will report below how the results change when hourly wages are used. 
full-time year-round workers are used (40 or more weeks per year, 35 or more hours per week), as a further test of whether variation in hours worked or weeks worked affects the weekly wage estimates (many studies in the area use such wages, e.g., Acemoglu and Autor, 2011). Those in group quarters, the military, the self-employed, and those with allocated earnings are also excluded from the wage sample, again following the studies just referenced. ${ }^{14}$ Weekly wages are put into 2007 dollars using the Personal Consumption Expenditure deflator.

Table 4 shows changes in the log real weekly wage by age and education for men and women, for comparison with the employment-population changes shown in Table 1. For men, there is a rough positive correlation between wage changes and employment changes from 1999 to 2007 but considerably less relationship from 1989 to 1999 . However, there is also a positive relationship between the difference in wage changes in the two periods and the difference in employment changes, with some of the largest reductions in wage changes from the 1989-1999 period to the 1999-2007 period occurred among younger and less educated individuals, which is where the employment changes were also the largest. For women, there is much less relationship. Most age-education groups experienced wage increases from 1999 to 2007, not decreases, although it is also the case that the wage increases were typically even larger from 1989 to 1999.

${ }^{14}$ The exclusion of those with allocated earnings makes no difference to the results. In addition, following Acemoglu and Autor (2011, p.1162), weekly wages are trimmed at the top and bottom, both to eliminate outliers and to eliminate those affected by top-coding. However, rather than trim at fixed real weekly wages values for all years, as they do, I trim the top and bottom 5 percent of the distribution. All wage regressions are estimated using March CPS Supplement weights. 
In estimating the model with wages, a well-known problem extensively addressed in the labor supply literature is that wage rates are not observed for nonworkers and must be imputed. I follow the fixed-effects approach described in equation (1) above by first regressing real log weekly wages on the $\mathrm{X}_{\mathrm{i}}$ vector (age-education-race dummy variables, separately by gender) separately for the three years in question-1989, 1999, and 2007. Because the March CPS in those years reports earnings and weeks worked in the prior calendar year, I select the sample and estimate these regressions using the 1990, 2000 and 2008 CPS surveys, respectively. I then impute log weekly wages to all individuals in the March 1989, 1999 and 2007 CPS using the estimated equations from their respective years and enter this variable into the $\mathrm{V}_{\text {it }}$ vector. The coefficient on predicted log weekly wages is thus identified by the covariance between the change in employment probabilities and the change in predicted wages conditional on ageeducation-race group, averaged over the groups. Put differently, this is the individual-data equivalent of a first-differenced grouped-data regression in which the change in the mean employment-population ratio in each group is regressed on the change in the log real weekly wage for that group, conditional on the other variables in the $\mathrm{V}_{\text {it }}$ vector (nonlabor income, demographic characteristics). ${ }^{15}$

For the purposes of the analysis here, I do not ask or investigate what the source of the change in wages is, and the literature on changes in the wage structure in the U.S. over the last

${ }^{15}$ Estimation on the individual data is more efficient because it makes use of withingroup covariances of the variables in the $\mathrm{V}_{\text {it }}$ vector. Formally, either the individual-data approach or the grouped-data approach is equivalent to an instrumental-variable procedure where "year" is the variable included in the wage equation--because it is estimated separately by year-but excluded from the employment-population regression, which restricts all parameters to be the same over all years. This equivalence is demonstrated by Moffitt (1993) in a discussion of the 
several decades is replete with alternative explanations for differential wage movements by education, experience, and gender. In addition, I implicitly assume that wage changes are the result of shifts in labor demand for different groups, rather than shifts in the labor supply curve. If the latter occurs, some of the wage coefficients could be negative, and this will be revealed by the results. The object of the exercise here is to determine how far one can go with a traditional labor supply model in explaining changes in the employment-population ratio, not to estimate a general equilibrium model of the labor market.

Another well-known problem since the work of Heckman (1974) is that wages of workers alone may be a biased measure of those of nonworkers and, for the issue studied here, changes in employment over time may result in biased effects of wage changes if only workers' wages are used because those who enter or exit employment may have systematically different wages than those who do not. For the main results reported, I employ a semiparametric version of the traditional Heckman (1979) approach, one not requiring the normality assumption. Reduced-form, first-stage OLS estimates of the employment equation in each year (leaving out the wage) are used to predict probabilities of employment, and a polynomial in those predicted probabilities is then entered into the wage equation estimated on workers only. The selectionbias effect is identified because the employment equation contains variables—nonlabor income and some demographic variables—which are excluded from the wage equation. The predicted wage from this equation, obtained by setting the predicted probability equal to one (which is equivalent to setting the normal-distribution-based lambda variable to zero), is then used in the employment equation.

work of Browning, Deaton, and Irish (1985). 19 
As a sensitivity test, I also test the use of a modified form of imputation of wages to nonworkers employed by Juhn et al. (1991) and Juhn (1992), modified slightly in a way suggested by Blau and Kahn (2007). I also estimate the model with no selection-bias adjustment at all.

Nonlabor Income. The typical difficulty in constructing a variable for nonlabor income is that few types of such income are exogenous. Means-tested transfer income is inversely related to income and therefore to employment and hence is endogenous, and most social insurance program benefits, such as UI, DI, and Social Security are likewise negatively related to employment (Social Security at certain ages is an exception). The typical labor supply study restricts the nonlabor income variable to include interest, dividends, and rent, which are contemporaneously independent of labor market activity. However, these types of capital income are the result of past accumulation of capital and that is no doubt related to earnings as well. Moreover, large fractions of the population receive no capital income at all. A third type of income sometimes included is earnings from members of the family other than the individual in question. The leading example is spousal earnings. However, this variable is also likely endogenous if the spouses coordinate their labor supply decisions.

Solving this old and difficult problem is beyond the scope of this study, so here I simply include interest and dividends in the measure of nonlabor income, excluding rent received for data reasons. ${ }^{16}$ Some sensitivity tests are conducted including earnings received by other

16 The Census imputes rent received for many observations, with the result that a large fraction of the data has negative values for this form of income. In addition, very few families receive any income at all from this source. 
members of the family. The nonlabor income variable is converted to a weekly amount and put into 2007 PCE dollars.

Demographic Variables. As noted in the review of labor supply models above, the presence of children, marital status, and other family structure variables have been shown in the literature to have strong effects on labor supply, albeit quite differently for men and women. Here I construct a three category marital status variable-Married, Single, or DivorcedWidowed-Separated — and include variables for the number of young children (0 to 5) and older children (6 to 18). In addition, variables are also included which indicate whether the individual is the head of the household or an unmarried parent (essentially an interaction between marital status and children). These variables are potentially endogenous but this issue is not addressed.

Results. Table 5 shows the results for the main model for men and women. ${ }^{17}$ The wage coefficient for men is .06, implying that a 10-percent increase in the log weekly wage would raise the employment-population ratio by .006. This corresponds to an elasticity of approximately .08, not large but consistent with the labor supply literature showing fairly inelastic labor supply curves for men. The wage elasticity for women is positive but insignificant. This result simply reflects the lack of correspondence between the wage and employment changes from 1989 to 2007 shown in Tables 1 and 4. Further results for women

${ }^{17}$ The standard errors shown are not adjusted for the two-stage nature of the estimation. Boostrapped standard errors are preferred but those estimates are biased and inconsistent if used with weighted data. Instead, the model was estimated without weights and the standard errors with and without bootstrapping were compared. The bootstrapped standard errors on the wage coefficient were two-to-four times those which were unadjusted. This would not affect the significance levels of the wage coefficients in Table 5 at conventional levels. The standard errors on the other coefficients were unaffected. 
which separate the estimates by marital status, and which yield different estimates, will be discussed momentarily.

The other variables have coefficient signs and significance levels expected from the past literature. Nonlabor income has a negative effect on labor supply, young children reduce the employment probabilities of women, older children also reduce that of women but increase employment for men, and married men have greater labor supply than unmarried men while women exhibit the opposite relationship. Household heads work more as do unmarried parents, another common finding in the literature.

Table 6 compares the actual mean changes in the employment-population ratios in the two periods to those predicted by the estimated models. ${ }^{18}$ For men, the model explains all ofin fact, more than--the small decline in the 1989-1999 period. However, it only explains about half of the decline in the 1999-2007 period. For women, the models explain a little over half the growth of the ratio in the first period but none of the decline in the second. ${ }^{19}$

Table 7 shows how the variables in the model changed between the periods, providing the source of the model predictions. Focusing only on the 1999-2007 period, the predicted decline in the male employment-population ratio is accounted for the decline in wages, the number of older children, the fraction married, the fraction divorced or widowed or separated men, and the fraction head of household. In terms of relative importance, multiplying each of these variables by its coefficients shows that the wage decline dominates the other influences in

18 Standard errors are not shown because the sample sizes (see n.12) are so large as to make them quite small.

19 Separate model estimates for the 1989-1999 and 1999-2007 periods show substantial differences in elasticities. Indeed, the women's wage elasticity in 1999-2007 is negative, 
magnitude, with the decline in the fraction married second in importance. For women, virtually every variable changed in a direction that would increase employment rather than cause it to decline, including an increase in wages and declines in nonlabor income, the number of children, and the fraction married. This explains why no decline in employment was predicted for women in Table 6.

Table 8 shows how well the model captures the age-education patterns of employment declines from 1999-2007 which were shown in Table 1. For women, the model captures very little of the pattern of greater declines for younger and less educated women, but this is not surprising given the lack of overall explanatory power of the model. For men, the model captures some of the relatively greater decline for younger men (except for those with less than a high school education) but captures the greater decline among the less educated only for older men. The model is therefore only partially successful, at best, at capturing these patterns. Further Exploration of Patterns by Marital Status and Presence of Children. The lack of explanatory power of the model for women, together with the descriptive evidence noted previously that the employment-population ratios for women were concentrated among the unmarried and, within that group, among those without children, suggests that disaggregation of the model by marital status and presence of children may be warranted. In fact, an inspection of the wage data for women reveals that the log weekly wage fell for married women over the 1999-2007 period but rose for unmarried women. Among the latter, wages rose for those with children and fell for those without children. While this does not necessarily imply that the

reflecting the fact that women's wages rose over that period and their employment declined. 
models estimated above are misspecified, it is worth investigating whether the wage and other coefficients are different for the different groups.

To this end, the model is estimated for married and unmarried women separately, and for unmarried women with and without children separately. ${ }^{20}$ The results are shown in Table 9. For married women, the wage coefficient is .076 and significant at conventional levels, quite different than that estimated for all women combined. Married women's wages rose strongly in the 1990s and, as just noted, they fell from 1999 to 2007, so the model is much more successful in explaining both the growth of employment in the first period and the decline in the second (in fact, the decline is overpredicted in the second). ${ }^{21}$ But the lion's share of the female employment decline occurred, in any case, among the unmarried, and here the estimated model yields an implausible negative wage elasticity when estimated over that subsample. ${ }^{22}$ This estimate is a simple result of the fact that wages for all unmarried women rose over the period while their employment fell. However, a further disaggregation into those unmarried women with and without children yields, as shown in the table, quite different results. After disaggregation, both wage elasticities are positive and, for women without children, where the majority of the employment decline occurred, the model predicts an employment decline not far

${ }^{20}$ Marital status and childbearing are likely to be endogenous variables, at least to some extent, and any bias arising from their endogeneity could be made worse by this stratification. If there are unobservables which affect both marital status, childbearing, and employment, and especially if the composition of different marital status and childbearing groups is changing over time, bias could arise. This issue should be addressed in future research.

${ }^{21}$ Models for married women were also estimated including the husband's wage. The results did not change the general tenor of the results and hence are not presented for brevity.

${ }^{22}$ A negative wage elasticity could be the result of some type of endogeneity, or from a supply shock instead of a demand shock. However, it would be surprising if either of these occurred only for this subgroup of women and not for any other women or for men. 
from the actual decline. This prediction arises because wages fell for unmarried women without children, as noted above. Indeed, the wage decline dominates the influence of all the other variables in the model in magnitude. ${ }^{23}$ The model does a poor job of explaining the small decline in employment for unmarried women with children, however, predicting instead an increase of some magnitude.

These results suggest that further investigation for the reasons for the differences in elasticities and in wage changes for the different marital status and parental groups of women should be investigated. The fraction of women who were married and who had children were declining over the period and this could be related to the employment changes, for example. It is also something of a puzzle as to why wage rates moved in such different sections for some of the demographic subgroups, who should be expected to operate in roughly the same labor market. This and other issues need to be explored.

\section{Taxes and Transfers}

As noted in the literature review above, taxes and transfers are often hypothesized to reduce labor supply and employment. The question addressed in this section is whether there is

${ }^{23}$ The wage elasticity for the two groups combined is positive because the wage increase for unmarried women with children was particularly large but their employment decline was small, while the wages of unmarried women without children had modest declines in the wage but large declines in employment. Thus the wage and employment changes for the two groups combined are negatively correlated. 
prima facie evidence for the effects of those policies on employment specifically between the 2000 to 2007 period.

Taxes. There were no federal income tax changes during the period 2000-2007 that would induce declines in labor supply over the period and, in fact, many would suggest the opposite. The Economic Growth and Tax Relief Reconciliation Act of 2001 passed by Congress provided for lower marginal tax rates at all income levels to be phased in gradually over the period 2001-2006, repealed the phaseout of the itemized deduction and personal exemption by 2008, and made some tax rate reductions retroactive. The Jobs and Growth Tax Relief Reconciliation Act of 2003 accelerated some of those reductions and reduced capital gains tax rates, and the Working Families Tax Relief Act of 2004 accelerated the provisions of both prior Acts.

The relevant tax rate for the employment decision, rather than the marginal hours-worked decision, is the average tax rate (ATR). Table 10 shows the ATR for all returns in each of the years 2000 to 2007 as well as the ATR for selected nominal income ranges. The ATR fell both overall and for all income ranges almost monotonically over time, which should have led to an increase in the employment rate rather than its opposite.

Other taxes during this period either did not change, increased only slightly, or fell. The payroll tax (FICA) below the taxable maximum remained at 7.65 percent over the period, unchanged from its value in 1990. The taxable maximum did rise, however, leading to a slight increase in the ATR for those at higher income levels, although this rise was because the taxable maximum level is indexed. The phase-in and phase-out tax rates for the Earned Income Tax Credit were unchanged from 1996 to 2008, although the income level for the maximum credit 
and for the complete phaseout moved up, increasing work incentives for lower earnings and decreasing them for higher earners. Capital gains and dividend tax rates have generally fallen, and estate and gift tax rates have been reduced and exemption levels raised.

Transfers. The U.S. system of transfers includes both programs which provide meanstested transfers--that is, transfers based directly on the income of the recipient and which require low income and/or low assets for eligibility--and social insurance programs, where eligibility and benefits are based on past earnings contributions. The leading means-tested programs in terms of expenditure and caseloads are the Medicaid, Supplemental Security Income (SSI), Temporary Assistance for Needy Families (TANF), Supplemental Nutritional Assistance (SNAP, formerly known as Food Stamps), and Housing programs. The leading social insurance programs are the Old Age and Survivors Insurance, Medicare, UI, and Disability Insurance programs.

Theoretically, most of the programs can be expected to reduce work incentives and hence to lead to lower levels of work effort, although there are many specific provisions that could go either way which will not be discussed here. More important is the empirical literature on the existence and size of those disincentives, and here the literature is quite large for some programs and quite small for many others. The literature was recently reviewed by Ben-Shalom et al. (forthcoming), who found the evidence on work disincentives to be modest for most programs and very sparse for some. There is virtually no research evidence on the work disincentives of the current TANF program, for example, and very little for the SSI program. However, the TANF caseload is extremely small and is very unlikely to contribute to the widespread employment-population declines in the data, and the SSI program only affects the aged and disabled. There have been a few studies of the work disincentives of expansions of the 
Medicaid program which have shown zero or negligible effects (Gruber, 2003; Ham and ShoreSheppard, 2005). The SNAP program appears to have work disincentives that are quite small, primarily because the benefit in question (food coupons) is not sufficiently large to provide much additional income as a result of reduced work effort. A recent study of the work disincentives of U.S. housing programs shows those programs to have significant work disincentives, about 4 percent points in employment (Jacob and Ludwig, 2012). However, once again, housing subsidy recipients are a restricted set of the population.

As for social insurance programs, there is a vast literature on the effects of the Social Security Retirement program on retirement ages and the labor supply of the elderly, but this is not germane to the employment-declines of the non-elderly studied here. Evidence on the impact of the program on work levels of the non-aged is too sparse to reach any reliable conclusions. There have been a few recent studies of the effect of Medicare on labor supply (e.g., French and Jones, 2011) which suggest that there may be non-trivial work incentives but, once again, only for those 55 or older. Research on the disincentive effects of the Disability Insurance program has been increasing because of the growth of caseloads and expenditures in the program. There is no consensus on its work disincentive effects, with studies using traditional benefit-employment correlations (e.g., Autor and Duggan, 2000) showing larger disincentives than studies using rejected applicants as a control group, which show much smaller effects (Bound et al., 2010). ${ }^{24}$ There is a very large literature on the work disincentives of the UI program but very little consensus on the magnitude of the effects. Restricting ourselves to the 
effects of the basic UI program itself and not considering the effects of extensions--there was no difference in UI Extended Benefits in 2000 and 2007--the most cited study is that recent work of Chetty (2008), which implies non-trivial work disincentives on the program on unemployment spell lengths.

More important for present purposes is whether any of these programs grew in size over the 1999-2007 period and, if so, whether there was any significant change in the structure, eligibility, or benefits of those programs over that period. Figure 4 shows the growth of the per capita caseloads of the major means-tested transfer programs since 1970. The figure demonstrates that there was little or no growth in those caseloads between 1999 and 2007 except for the Medicaid and SNAP programs; there was very little growth in the SSI or Housing caseloads over the 2000-2007 period, and the TANF caseload actually declined. The growth of Medicaid was a result of 1999 legislation creating the Children’s Health Insurance Program (CHIP, later renamed SCHIP) which expanded coverage to children. This expansion should have had only an indirect impact on adult work effort. In addition, the growth of the Medicaid program began much earlier, in the late 1980s as a result of expansionary reforms for coverage of children and pregnant women which continued to have an impact over succeeding years.

The program whose per capita caseload increase is more relevant is the SNAP program, which began growing around 2000 and continued to grow thereafter (and has accelerated during the Recession). The reasons for the growth of the program in this period were related to administrative reforms in the program intended to increase the participation rate of eligible

${ }^{24}$ However, Von Wachter et al. (2011) have found that even the rejected-applicant methodology shows growing work disincentives over time as a result of changes in the 
families, which historically had been only around 60 percent. Beginning in the late 1990s and early 2000s, the U.S. Department of Agriculture began strongly encouraging states to make it easier to participate in the program. These activities included extensive outreach programs to inform low income communities about the program; simplified eligibility criteria which reduced paperwork requirements for application; reduced recertification requirements requiring less reporting and less frequent reestablishment of eligibility; and relaxed asset test requirements for the program (Leftin and Wolkwitz, 2009). These reforms have been found to be a major cause of the increase in the caseload (Klerman and Danielson, 2009).

Although the prior research has estimated the SNAP program to have very small work disincentives if any, it is possible that the marginal individuals brought into the program by these administrative reforms could have had higher levels of initial employment and perhaps stronger employment reductions from receiving program benefits. Although no direct evidence on this question is available, Table 12 shows where the increase in participation from 2000 to 2007 occurred in the income distribution. As the table indicates, the increases in participation were concentrated among the very poorest families in the economy, those with incomes less than 25 percent of the poverty line. ${ }^{25}$ While it is in principle possible that the low incomes of these families are partly the result of program participation, it seems unlikely that their employment levels would be very high in the absence of participation, as might have seemed more possible if the participation increases had occurred somewhat higher in the distribution. In any case, more research on this question is needed.

composition of the caseload.

${ }^{25}$ Recall that the official definition of income excludes SNAP benefits. 
Figure 5 shows the growth in the per capita caseloads of the two social insurance programs for the nonelderly, UI and DI. The UI caseload was approximately the same in 2000 and 2007, not surprisingly since the unemployment rate was the same in those years as well and no structural reforms of the program took place between those years. The DI program, on the other hand, continued growth which began in 1990 (and which has continued into the Recession). ${ }^{26}$ Much research has been conducted on the causes of this growth; declining wages for the low-skilled population may be one factor responsible, but changes in administrative procedures that effectively allow more eligibles onto the program are thought to be another (Bound et al., 2010).

A new study of the disincentive effects of the DI program is beyond the scope of this paper, but a relevant piece of evidence that can be gleaned from the CPS is whether the magnitudes and pattern of increases in DI receipt across the age-education groups-receipt of DI benefits is reported in the survey—matches up with the patterns of employment declines. Table 11 shows how DI receipt reported in the CPS changed between 1999 and 2007 for the different groups of men and women and provides little basis for concluding that DI has played much of a role in employment declines. Some of the youngest and least skilled groups have seen increases in receipt but the magnitudes are tiny compared to the declines in the employment-population ratios shown in Table 1. Many older groups have also seen declines in receipt. Indeed, while the fraction of the caseload that is composed of somewhat younger men has increased in recent

${ }^{26}$ The rate of applications is much more volatile than the slow-moving stock shown in the figure (David Autor, personal correspondence). Moreover, applications are also correlated with work disincentives because applicants typically do not work until an award decision is made, which could be as much as five years later. The application rate per 1000 persons 25-64 
decades (Von Wachter et al., 2011), the caseload is still dominated by older men; in our CPS data, more than 3 percent of some of the 55-64 age groups were receiving disability income but never more than half a percent of those less than 40 were. Thus the patterns of receipt of this type of transfer does not match up well with the age patterns of the employment-population ratio decline. ${ }^{27}$

In summary, there have been few changes in the tax and transfer system that are likely to have contributed to the decline in employment-population ratios. Changes in income tax rates fell rather than increased and there were no other significant changes in the tax systems. Most transfer programs did not experience programmatic reforms and those that experienced significant caseload growth over the 1999-2007 period are unlikely to have played a major role in the employment declines, although more study of the SNAP program in this regard would be warranted.

in the population was 8.25 in 1999 and 13.72 in 2007.

${ }^{27}$ DI receipt is endogenous and can be as much a result of employment declines as its cause. Therefore, if the pattern of receipt were to match up well with the pattern of employment declines, no causal conclusions could be drawn. However, the failure of them to match up well constitutes legitimate evidence in the opposite direction, that the program is unlikely to have played a major role. 


\section{Other Possible Factors}

Several other possible factors in influencing the decline in employment-population ratios are worthy of consideration. These include changes in time use, health status, incarceration, and the minimum wage.

Time use. Time use could be a contributing explanation to the decline in the employment-population ratio if that decline was accompanied by an increase in nonmarket work, household production, or time devoted to child care. While such a shift would itself require an explanation, it would obviously suggest a concrete direction for exploration. Unfortunately, examining this hypothesis specifically for the 1999-2007 period is severely limited by the data. Modern analyses of time use begin with the American Time Use Survey (ATUS), whose first year was 2003. As emphasized repeatedly here, 2003 was at the trough of a business cycle and unemployment was at a peak (see Figure 2) and, consequently, one should expect declines in employment and probable increases in nonmarket work between 1999 or 2000 and that year. However, no time use survey is available in 1999 or 2000 in any case. Prior to the 2003 ATUS, the most reliable recent survey was conducted in 1985, far too early to draw conclusions for the time period under consideration here. Further, over that period, Aguiar and Hurst (2007) have shown that nonmarket work time actually declined, which would not go in the right direction for explaining downward trends in employment. A 1994 survey exists but is widely regarded as fairly unreliable, often providing counterfactual results, and its time use categories are not completely comparable to those used in the ATUS. Aguiar and Hurst also analyzed that survey, 
however, and also found that nonmarket work declined from 1994 to 2003, albeit by a smaller amount than from 1985 to 2003.

Aguiar et al. (2011) used the ATUS to chart nonmarket work time from 2003 to 2007 and beyond (their paper was more focused on trends in the Recession). Their data showed that there were strong increases in market work and declines in nonmarket time from 2003 to 2007. Again, however, this was unquestionably a cyclical recovery period and this direction of effect is exactly what one would expect for that phase of a cycle.

There is somewhat better data specifically on time spent in child care time, with some data available in 2000 as well as later years. Analyzed by Ramey and Ramey (2010), the authors found an upward trend in child care time among parents in the U.S. This is some evidence in support of the hypothesis of the decline in employment. However, the educational pattern in the child care trend was exactly the opposite of that in the employment-population ratio, as demonstrated previously: while the declines in employment were disproportionately concentrated among the less educated--and, as we have learned in the previous section, among the unmarried--the increases in child care time were concentrated among the higher educated, married individuals.

Health. A decline in health is another possible factor that could contribute to declines in employment. Although one would naturally expect health to improve for a population with growing income per capita over time, it need not necessarily improve over shorter periods of time, particularly for particularly disadvantaged subgroups within the population. Measurement is a difficult issue in measuring health status as well, because the use of medical records to determine trends in specific morbidity rates is subject to bias because improved medical 
procedures generally result in greater detection of disease. The most common measure of health status is a self-rated measure from survey questions asking whether an individual's health is excellent, good, fair, or poor. This question is used in the CPS as well as in the National Health Interview Survey and others. Unfortunately, time trends in the fraction of the population reporting different categories is dramatically different in different surveys--rising in some, falling in others, and stationary in others, including over the period 2000-2007 (Salomon et al., 2009). The CPS, in particular, shows improvements in health in almost all age, education, and race categories, so it is unlikely that this factor is a significant one in the employment-population trends under study here.

Incarceration. The well-known dramatic increase in the incarceration rate of disadvantaged men in the U.S. is another trend that could be related to the decline of male employment. ${ }^{28}$ The number of prisoners in federal or state prisons per 100,000 U.S. residents rose by almost five times between 1975 and 2009 (Pettit, 2012). Much of the increase was among less educated men, for the fraction of Non-Hispanic White men with less than a high school education who were incarcerated rose from 3.5\% in 1980 to $8.3 \%$ in 2008 and that for Non-Hispanic Black men rose from 9.6\% to 29.\% over the same years (Pettit, Table 3.1). The majority of the rise is a result of changes in sentencing and parole policy (Raphael, 2010).

This increase does not necessarily connect well to the employment declines studied here. The increases have been steady since the late 1970s or early 1980s and, if anything, slowed in the 2000s. In addition, the incarceration rate is heavily concentrated among minority men yet, as Appendix Table A-1 indicates, the employment declines were not particularly concentrated in 
the Non-Hispanic Black population. Further, the CPS figures on employment only include the non-institutionalized population and hence exclude men in prisons and jails. From a simple supply and demand framework, one would expect a reduction in the aggregate labor supply of low-educated men to lead to an increase in equilibrium wages and a consequent increase in employment among those men remaining.

Nevertheless, the potential impact of long-term increases in incarceration could be felt through its impact on the employment rates of men after having left prison. There is substantial evidence that past incarceration reduces the probability of being hired (Raphael, 2010) and, indeed, many employers have explicit rules against such hiring. Pettit (2012, Table 1.4) used data on the age distribution of prisoners over time to estimate cohort rates of cumulative imprisonment by ages 30 to 34 and found them to dramatically rise over time, including a change from 14.4\% of the less-than-high-school White male population in 1999 and $28.0 \%$ in 2009. For the Black male population, the rate rose from $46 \%$ to $68 \%$. While these rates were also increasing in prior decades, it is possible that the rates rose to such high levels in the 2000s that a particularly large negative impact on male employment rates occurred.

Minimum Wage. It is possible that wage rigidities could account for some of the 19992007 employment decline, which would also explain why wages are not playing a more important role in the labor supply models estimated in this paper. ${ }^{29}$ Low wage labor markets, at least those for the very unskilled, are typically non-unionized and fairly competitive, so it is

${ }^{28}$ I thank Steve Davis for suggesting this avenue of investigation.

${ }^{29}$ Shimer (2011) has, in this and other papers, suggested that wage rigidities could play an important role in labor force participation movements. However, his emphasis is on explaining cyclical movements rather than trends, which is not quite the same as the focus here. 
unclear whether wage rigidities are important for the groups that have been shown here to have experienced the largest employment declines. The only significant source of such rigidities is the minimum wage. However, trends in the national real minimum go in exactly the opposite direction as would be needed as a source explanation for the differential employment trends in the 1990s and the 2000s prior to 2007. The real minimum declined from 1974 to 1989, rose from 1989 to 1997, and then declined from 1997 to 2006. The minimum wage has risen dramatically since then, beginning with an increase in the minimum from \$5.15 per hour to \$5.85 per hour in July, 2007. This increase is after the March 2007 CPS and too late to have had any effect on trends prior to that time in any case.

\section{Summary and Implications for Post-Recession Employment}

The decline in the employment-population ratios for men and women over the period 1999-2007 prior to the Great Recession represents an historic turnaround in the evolution of U.S. employment. The decline is disproportionately concentrated in the less educated and younger groups within both the male and female populations and, for women, disproportionately concentrated among the unmarried and among unmarried women without children. A standard model which emphasizes the role of wage rates and nonlabor income can explain about half the decline for men but none of it for women, for women's wages rose, on average and for all women, over the period. However, separate examination of trends in wages and employment for married and unmarried women, and for unmarried women with and without children, gives wages a more important role. The decline in female employment was by far the largest for 
unmarried women without children and, for that group, wages declined over the period 19992007. However, the different trends in wage rates and other determinants of employment for these different demographic subgroups raise many questions which need to be explored.

Most other possible influences on employment rates also appear unlikely to have contributed to the 2000-2007 decline. Federal income tax rates fell rather than rose, other tax rates did not rise, and transfer programs did not change in structure or in patterns of growth that line up with the employment declines, although further study of the Supplemental Nutrition Assistance Program and the Disability Insurance Program would be worthwhile. Changes in health status, the minimum wage, and other factors also appear to have not played a role, although rising rates of incarceration among disadvantaged and younger men may have contributed. Whether changes in time use and home production accompanied the employment declines is not discernible with the available data, but could have occurred. Further analysis of possible contributors to the employment decline are clearly needed.

With the onset of the Great Recession, the employment-population ratio plummeted starting in 2008, falling to approximately 72 percent for men and 63 percent for women in 2009. It has exhibited a slow recovery since that time. Given the downward trend in the ratio prior to the Great Recession, a natural question is whether it will recover to its 2007 level after the completion of the recovery or whether it will return only to a lower level. The model estimated in this paper can be used to forecast employment-population ratios in 2011, the latest year for which Current Population Survey data are available. The results suggest that the ratios may fully return to their 2007 levels. The online Appendix to this paper describes the details of the calculation. 
Appendix

Table A-1 shows the employment-population ratio changes by race as well as by age and education.

Table A-2 shows the estimated wage equations for the main model, separately by year and gender, for the years 1989, 1999, and 2007 (estimated from the 1990, 2000, and 2008 March CPS). Demographic variables for marital status and headship are included on the presumption, supported by much of the literature, that much of the correlation between these variables and wage rates is causal. The predicted probability of being in the wage sample-which is not only the predicted probability of working during the year but also not satisfying any of the exclusions from the sample noted in the text-is taken from a first-stage reduced form OLS employmentstatus regression. ${ }^{30}$ The identifying variables are those for children and nonlabor income. The coefficient on the predicted probability is negative for men, which is consistent with positive selection (that is, nonworking men have lower wage rates than working men). However, the coefficient is positive for women, which is generally interpreted as implying that women with higher market wage rates have even higher reservation wages.

Table A-3 shows estimates of the wage coefficient from different methods of imputing wages and estimating the model, along with the predicted changes in employment probabilities for comparison to those in Table 6 in the text. The first row shows the effect of using no adjustment for selection bias in the wage equation. The wage coefficient for men is negative in 
this case while that for women is positive. For men, the declining employment rate leads to an increase in the wage conditional on working and this leads to a negative correlation between the wage change and employment change. For women, selection operates in the opposite direction, leading to a positive bias. However, the predicted changes in employment probabilities for the two time periods are very close to those in Table 6.

The second row shows the effect of imputing wages to nonworkers using a method closely related to that of Blau and Kahn (2007), who themselves adopted a method used by Juhn (1992) and Juhn et al. (1991). The latter two authors imputed wages of those who had worked 113 weeks to nonworkers, whereas Blau and Kahn estimated regressions separately for those who worked less than 20 weeks and those who worked 20 or more, and then imputed wages to nonworkers from the less-than-20-weeks regression. Here, separate wage regressions are estimated for those with less than 20 weeks worked, those with 20-39 weeks worked, and those with 40 weeks worked. Wages of nonworkers are imputed from the predicted values from the less-than-20-weeks regression, while wages for workers are predicted from a fixed weighted average of the wages predicted from the three regressions, using as weights the fractions of the sample that worked less than 20, 20 to 39, and 40 more in $1999 .{ }^{31}$ As the table shows, this method yielded much larger wage coefficients than that of the conventional method. The predicted changes in employment probabilities are always positive and considerably farther from the actual changes than the predictions from the conventional selection bias method.

\footnotetext{
${ }^{30}$ A quadratic predicted probability was also tested but yielded very similar results.

${ }^{31}$ I thank Steve Davis for suggesting this method.
} 
The third row shows the effect of restricting the wage equation to workers with 40 or more weeks of work per year and at least 35 hours worked per week, a common method of eliminating weeks and hours worked variation from the wage measure and obtaining something closer to an hourly wage (e.g., Acemoglu and Autor, 2011). The method runs the danger of selecting on an endogenous variable (weeks of work) but, perhaps more important, it results in a rather restricted set of observations for the wage sample. ${ }^{32}$ In some of the age-education cells, the fraction of the sample that is included in the wage regression is less than 10 percent and very often less than 25 percent (recall that allocated observations are also excluded). This makes selection bias adjustments more fragile as well as imputing wages from what may be a rather atypical sample to the full sample. This method yields somewhat smaller wage elasticities for men and somewhat larger ones for women. The employment-change predictions are slightly worse for men and very slightly better for women.

The fourth row shows the effect of using log real hourly wages instead of log real weekly wages in the model, using the CPS variable for average hours worked in the prior year. The male wage coefficients and employment predictions from this model are very close to those using the weekly wage but the results for females are quite different, with a negative wage elasticity. This may be the result of a bias related to division bias. The employment-status predictions are slightly better than in the main model, mostly because wages of women were rising over the period while employment rates were falling, and a negative wage elasticity can explain this better than a positive one.

\footnotetext{
${ }^{32}$ I thank Steve Davis for emphasizing this point.
} 
The final row shows the effect of using probit for the first-stage reduced-form employment-status regression and for the final employment-status regression containing the predicted wage. The results are quite similar to those using the main model, which used OLS. 


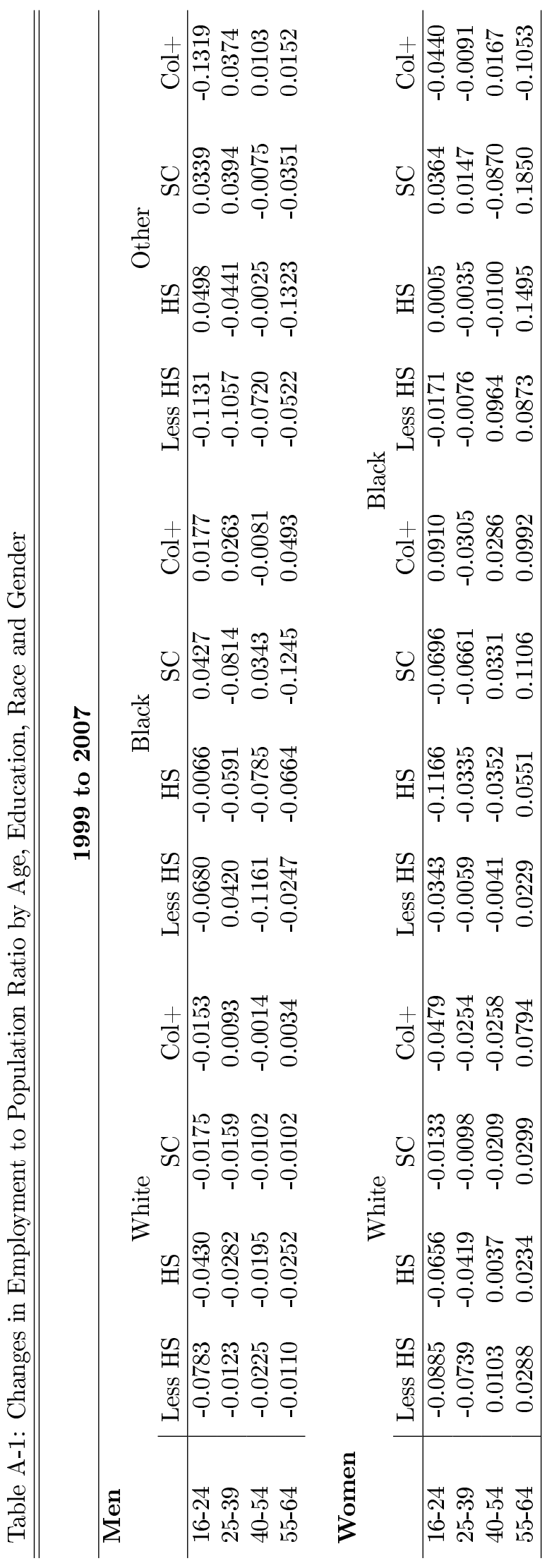

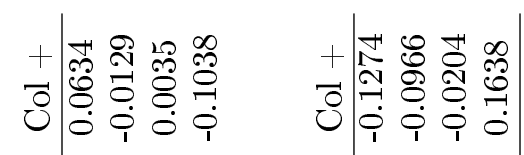

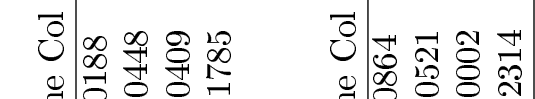

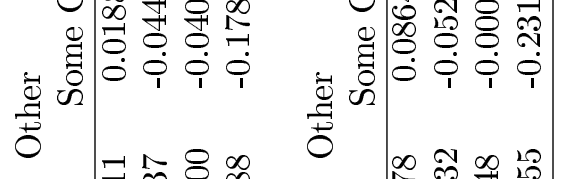

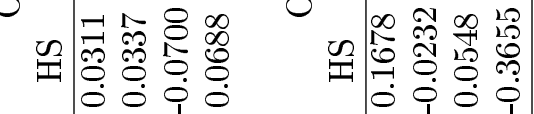
焉 管

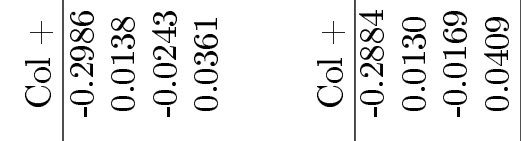

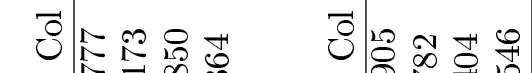

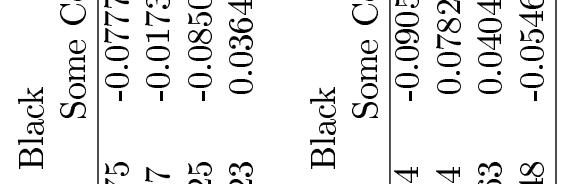

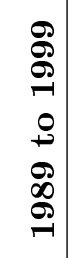

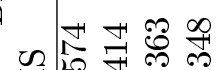

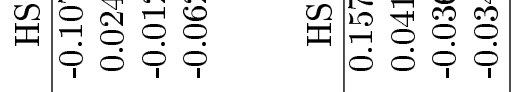

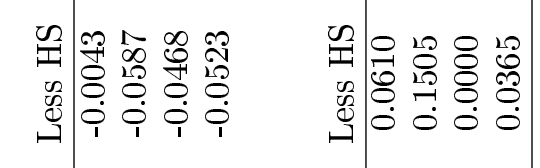

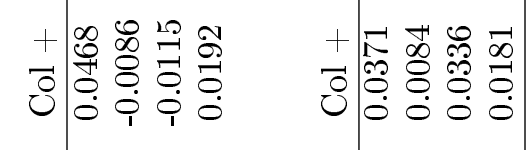
ت⿹

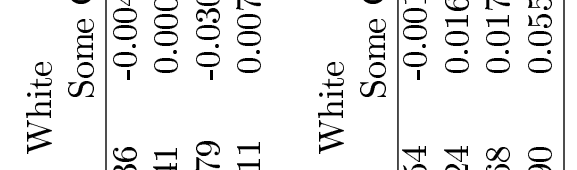

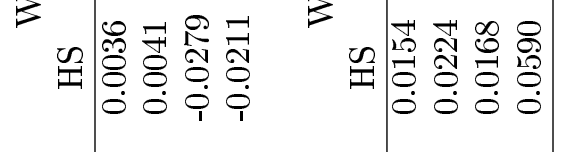

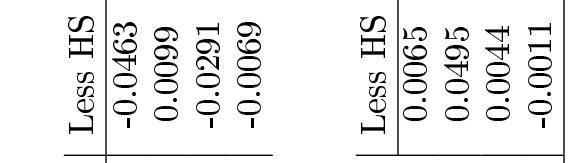

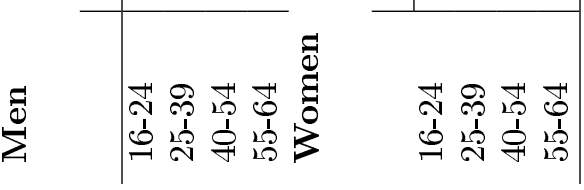


Table A-2(a): Estimates of Log Weekly Wage Regressions for Men

\begin{tabular}{|c|c|c|c|c|c|c|}
\hline \multirow[b]{2}{*}{ Married } & \multicolumn{2}{|c|}{$\begin{array}{c}(1) \\
1989\end{array}$} & \multicolumn{2}{|c|}{$\begin{array}{c}(2) \\
1999\end{array}$} & \multicolumn{2}{|c|}{$\begin{array}{c}(3) \\
2007\end{array}$} \\
\hline & 0.1877 & $(0.0113)$ & 0.2245 & $(0.0129)$ & 0.2666 & $(0.0151)$ \\
\hline Divorced, Widowed or Separated & 0.1032 & $(0.0155)$ & 0.1402 & $(0.0163)$ & 0.1858 & $(0.0176)$ \\
\hline Head of Household & 0.3820 & $(0.0229)$ & 0.4422 & $(0.0305)$ & 0.4951 & $(0.0428)$ \\
\hline Single Parent & 0.0267 & $(0.0271)$ & 0.1088 & $(0.0285)$ & 0.1549 & $(0.0290)$ \\
\hline Predicted Probability of Being in Wage Sample & -1.1896 & $(0.1392)$ & -1.8974 & $(0.2001)$ & -1.9502 & $(0.2754)$ \\
\hline age16to24lessHSwhite & -0.7807 & $(0.1858)$ & -1.0682 & $(0.0936)$ & -1.1286 & $(0.0823)$ \\
\hline age16to24lessHSblack & -1.0142 & $(0.1908)$ & -1.3750 & $(0.1154)$ & -1.2176 & $(0.1166)$ \\
\hline age16to24lessHSother & -0.7240 & $(0.2071)$ & -1.4232 & $(0.1206)$ & -1.3357 & $(0.1320)$ \\
\hline age16to24HSwhite & -0.0725 & $(0.1913)$ & -0.2415 & $(0.1074)$ & -0.2962 & $(0.0917)$ \\
\hline age16to24HSblack & -0.3372 & $(0.1904)$ & -0.5868 & $(0.1059)$ & -0.5805 & $(0.0894)$ \\
\hline age16to24HSother & -0.3502 & $(0.2026)$ & -0.4196 & $(0.1372)$ & -0.4186 & $(0.1210)$ \\
\hline age16to24SCwhite & -0.2089 & $(0.1901)$ & -0.3887 & $(0.1041)$ & -0.4275 & $(0.0853)$ \\
\hline age16to24SCblack & -0.3045 & $(0.1965)$ & -0.6508 & $(0.1057)$ & -0.5535 & $(0.1064)$ \\
\hline age16to24SCother & -0.3856 & $(0.1949)$ & -0.4888 & $(0.1325)$ & -0.9444 & $(0.1045)$ \\
\hline age16to24Colwhite & 0.1594 & $(0.1945)$ & 0.0463 & $(0.1187)$ & 0.0070 & $(0.1005)$ \\
\hline age16to24Colblack & -0.2279 & $(0.2721)$ & 0.1036 & $(0.1810)$ & -0.0627 & $(0.1809)$ \\
\hline age16to24Colother & -0.1372 & $(0.2228)$ & -0.4181 & $(0.1789)$ & -0.1714 & $(0.1745)$ \\
\hline age25to39lessHSwhite & -0.1160 & $(0.1884)$ & -0.3707 & $(0.1002)$ & -0.3985 & $(0.0882)$ \\
\hline age25to39lessHSblack & -0.4222 & $(0.1900)$ & -0.7051 & $(0.1059)$ & -1.0228 & $(0.1153)$ \\
\hline age25to39lessHSother & -0.1656 & $(0.2069)$ & -0.3123 & $(0.1210)$ & -0.3310 & $(0.1162)$ \\
\hline age25to39HSwhite & 0.2310 & $(0.1889)$ & 0.0629 & $(0.1030)$ & 0.0150 & $(0.0921)$ \\
\hline age25to39HSblack & 0.0410 & $(0.1910)$ & -0.0472 & $(0.1069)$ & -0.3868 & $(0.0831)$ \\
\hline age25to39HSother & 0.0602 & $(0.1959)$ & 0.0132 & $(0.1183)$ & -0.1987 & $(0.0997)$ \\
\hline age25to39SCwhite & 0.3312 & $(0.1887)$ & 0.2305 & $(0.1051)$ & 0.1551 & $(0.0970)$ \\
\hline age25to39SCblack & 0.2169 & $(0.1928)$ & 0.1367 & $(0.1126)$ & -0.0799 & $(0.0997)$ \\
\hline age25to39SCother & 0.0709 & $(0.1960)$ & 0.0106 & $(0.1194)$ & 0.1203 & $(0.1063)$ \\
\hline age25to39Colwhite & 0.4249 & $(0.1872)$ & 0.3472 & $(0.0996)$ & 0.3584 & $(0.0907)$ \\
\hline age25to39Colblack & 0.3921 & $(0.1962)$ & 0.3168 & $(0.1137)$ & 0.1440 & $(0.0947)$ \\
\hline age25to39Colother & 0.3332 & $(0.1923)$ & 0.3431 & $(0.1054)$ & 0.3953 & $(0.0930)$ \\
\hline age40to54lessHSwhite & -0.1180 & $(0.1865)$ & -0.4039 & $(0.0955)$ & -0.5339 & $(0.0762)$ \\
\hline age40to54lessHSblack & -0.2537 & $(0.1901)$ & -0.6206 & $(0.1083)$ & -0.7880 & $(0.0893)$ \\
\hline age40to54lessHSother & -0.1630 & $(0.1977)$ & -0.6319 & $(0.1277)$ & -0.5065 & $(0.1146)$ \\
\hline age40to54HSwhite & 0.2310 & $(0.1863)$ & -0.0054 & $(0.0948)$ & -0.1292 & $(0.0760)$ \\
\hline age40to54HSblack & 0.1363 & $(0.1902)$ & -0.2991 & $(0.1005)$ & -0.4074 & $(0.0799)$ \\
\hline age40to54HSother & 0.1196 & $(0.2031)$ & -0.4566 & $(0.1180)$ & -0.2116 & $(0.0893)$ \\
\hline age40to54SCwhite & 0.3078 & $(0.1860)$ & 0.1361 & $(0.0950)$ & 0.1009 & $(0.0786)$ \\
\hline age40to54SCblack & 0.2178 & $(0.1976)$ & -0.1928 & $(0.1012)$ & -0.1067 & $(0.0853)$ \\
\hline age40to54SCother & 0.2850 & $(0.2010)$ & -0.0272 & $(0.1135)$ & -0.0442 & $(0.1025)$ \\
\hline age40to54Colwhite & 0.3483 & $(0.1853)$ & 0.1812 & $(0.0913)$ & 0.2142 & $(0.0730)$ \\
\hline age40to54Colblack & 0.5071 & $(0.1938)$ & 0.1630 & $(0.1059)$ & 0.1255 & $(0.0873)$ \\
\hline age40to54Colother & 0.2330 & $(0.1931)$ & -0.0001 & $(0.1116)$ & 0.1902 & $(0.0866)$ \\
\hline age55to64lessHSwhite & -0.3785 & $(0.1874)$ & -0.7183 & $(0.0981)$ & -0.8851 & $(0.0923)$ \\
\hline age55to64lessHSblack & -0.4913 & $(0.1936)$ & -1.0092 & $(0.1424)$ & -1.1409 & $(0.1248)$ \\
\hline age55to64lessHSother & -0.4312 & $(0.2484)$ & -0.6960 & $(0.1737)$ & -1.1763 & $(0.1950)$ \\
\hline age55to64HSwhite & -0.1015 & $(0.1861)$ & -0.4461 & $(0.0937)$ & -0.3865 & $(0.0743)$ \\
\hline age55to64HSblack & -0.1324 & $(0.2109)$ & -0.7722 & $(0.1379)$ & -0.7293 & $(0.1071)$ \\
\hline age55to64HSother & -0.0316 & $(0.1964)$ & -0.5361 & $(0.1418)$ & -0.6273 & $(0.1208)$ \\
\hline age55to64SCwhite & 0.0906 & $(0.1874)$ & -0.3180 & $(0.0949)$ & -0.2760 & $(0.0750)$ \\
\hline age55to64SCblack & -0.3234 & $(0.2499)$ & 0.0103 & $(0.1204)$ & -0.5539 & $(0.1072)$ \\
\hline age55to64SCother & 0.0434 & $(0.2067)$ & -0.0457 & $(0.1476)$ & -0.0766 & $(0.1017)$ \\
\hline age55to64Colwhite & 0.0971 & $(0.1873)$ & -0.1990 & $(0.0969)$ & -0.0671 & $(0.0758)$ \\
\hline age55to64Colblack & 0.1726 & $(0.2130)$ & -0.2771 & $(0.1360)$ & -0.0395 & $(0.1205)$ \\
\hline Constant & 6.6765 & $(0.1915)$ & 7.2328 & $(0.1117)$ & 7.1682 & $(0.1098)$ \\
\hline Observations & 27168 & & 20883 & & 21456 & \\
\hline
\end{tabular}

Standard errors in parentheses 
Table A-2(b): Estimates of Log Weekly Wage Regressions for Women

\begin{tabular}{|c|c|c|c|c|c|c|}
\hline \multirow[b]{2}{*}{ Married } & \multicolumn{2}{|c|}{$\begin{array}{c}(1) \\
1989\end{array}$} & \multicolumn{2}{|c|}{$\begin{array}{c}(2) \\
1999\end{array}$} & \multicolumn{2}{|c|}{$\begin{array}{c}(3) \\
2007\end{array}$} \\
\hline & -0.0581 & $(0.0137)$ & 0.0041 & $(0.0160)$ & 0.0042 & $(0.0153)$ \\
\hline Divorced, Widowed or Separated & 0.0269 & $(0.0150)$ & 0.0163 & $(0.0147)$ & 0.0226 & $(0.0153)$ \\
\hline Head of Household & 0.1145 & $(0.0144)$ & 0.0374 & $(0.0180)$ & 0.0456 & $(0.0198)$ \\
\hline Single Parent & -0.0581 & $(0.0156)$ & -0.1114 & $(0.0158)$ & -0.1491 & $(0.0172)$ \\
\hline Predicted Probability of Being in Wage Sample & 0.8119 & $(0.0737)$ & 0.8558 & $(0.1176)$ & 0.7332 & $(0.1272)$ \\
\hline age16to24lessHSwhite & -1.1240 & $(0.1335)$ & -1.2940 & $(0.0987)$ & -1.2590 & $(0.1064)$ \\
\hline age16to24lessHSblack & -1.1174 & $(0.1414)$ & -1.1194 & $(0.1189)$ & -1.2303 & $(0.1235)$ \\
\hline age16to24lessHSother & -1.0255 & $(0.1618)$ & -1.0065 & $(0.1272)$ & -1.1757 & $(0.1318)$ \\
\hline age16to24HSwhite & -0.9653 & $(0.1355)$ & -1.1790 & $(0.0996)$ & -1.0876 & $(0.1074)$ \\
\hline age16to24HSblack & -0.8195 & $(0.1401)$ & -1.0959 & $(0.1067)$ & -1.1134 & $(0.1180)$ \\
\hline age16to24HSother & -0.7396 & $(0.1600)$ & -1.0354 & $(0.1317)$ & -1.0214 & $(0.1314)$ \\
\hline age16to24SCwhite & -0.9456 & $(0.1361)$ & -1.1845 & $(0.0985)$ & -1.1692 & $(0.1071)$ \\
\hline age16to24SCblack & -0.8072 & $(0.1452)$ & -1.1283 & $(0.1114)$ & -1.0229 & $(0.1175)$ \\
\hline age16to24SCother & -0.8674 & $(0.1529)$ & -1.0853 & $(0.1152)$ & -1.0516 & $(0.1251)$ \\
\hline age16to24Colwhite & -0.5456 & $(0.1394)$ & -0.8665 & $(0.1075)$ & -0.7993 & $(0.1167)$ \\
\hline age16to24Colblack & -0.7490 & $(0.2256)$ & -0.6739 & $(0.1873)$ & -0.5644 & $(0.1452)$ \\
\hline age16to24Colother & -0.5420 & $(0.1601)$ & -0.3117 & $(0.2798)$ & -0.4001 & $(0.1732)$ \\
\hline age25to39lessHSwhite & -0.6771 & $(0.1341)$ & -0.9470 & $(0.0976)$ & -0.9617 & $(0.1065)$ \\
\hline age25to39lessHSblack & -0.7218 & $(0.1405)$ & -0.9274 & $(0.1066)$ & -1.0077 & $(0.1221)$ \\
\hline age25to39lessHSother & -0.5363 & $(0.1480)$ & -0.9742 & $(0.1357)$ & -1.0658 & $(0.1340)$ \\
\hline age25to39HSwhite & -0.5845 & $(0.1341)$ & -0.7839 & $(0.0968)$ & -0.8043 & $(0.1061)$ \\
\hline age25to39HSblack & -0.6033 & $(0.1361)$ & -0.7942 & $(0.1011)$ & -0.8074 & $(0.1097)$ \\
\hline age25to39HSother & -0.5210 & $(0.1433)$ & -0.8295 & $(0.1109)$ & -0.7907 & $(0.1193)$ \\
\hline age25to39SCwhite & -0.4044 & $(0.1344)$ & -0.6818 & $(0.0977)$ & -0.6860 & $(0.1090)$ \\
\hline age25to39SCblack & -0.4818 & $(0.1379)$ & -0.6219 & $(0.1007)$ & -0.6556 & $(0.1122)$ \\
\hline age25to39SCother & -0.3395 & $(0.1487)$ & -0.7177 & $(0.1107)$ & -0.6469 & $(0.1171)$ \\
\hline age25to39Colwhite & -0.1140 & $(0.1340)$ & -0.3256 & $(0.0974)$ & -0.3515 & $(0.1093)$ \\
\hline age25to39Colblack & -0.1662 & $(0.1387)$ & -0.3714 & $(0.1040)$ & -0.3985 & $(0.1159)$ \\
\hline age25to39Colother & -0.0080 & $(0.1388)$ & -0.2509 & $(0.1038)$ & -0.2465 & $(0.1121)$ \\
\hline age40to54lessHSwhite & -0.5621 & $(0.1341)$ & -0.8503 & $(0.0975)$ & -0.8812 & $(0.1052)$ \\
\hline age40to54lessHSblack & -0.5529 & $(0.1416)$ & -0.8556 & $(0.1137)$ & -0.7786 & $(0.1246)$ \\
\hline age40to54lessHSother & -0.4577 & $(0.1498)$ & -0.6909 & $(0.1325)$ & -0.9073 & $(0.1206)$ \\
\hline age40to54HSwhite & -0.4517 & $(0.1334)$ & -0.6823 & $(0.0965)$ & -0.6872 & $(0.1055)$ \\
\hline age40to54HSblack & -0.4322 & $(0.1369)$ & -0.7375 & $(0.1007)$ & -0.7132 & $(0.1088)$ \\
\hline age40to54HSother & -0.4148 & $(0.1436)$ & -0.6229 & $(0.1173)$ & -0.7345 & $(0.1169)$ \\
\hline age40to54SCwhite & -0.2884 & $(0.1342)$ & -0.5074 & $(0.0969)$ & -0.5098 & $(0.1067)$ \\
\hline age40to54SCblack & -0.2795 & $(0.1420)$ & -0.4427 & $(0.1025)$ & -0.4769 & $(0.1100)$ \\
\hline age40to54SCother & -0.1629 & $(0.1550)$ & -0.4200 & $(0.1194)$ & -0.6584 & $(0.1179)$ \\
\hline age40to54Colwhite & -0.0546 & $(0.1338)$ & -0.2070 & $(0.0960)$ & -0.1959 & $(0.1045)$ \\
\hline age40to54Colblack & 0.0868 & $(0.1440)$ & -0.1078 & $(0.1034)$ & -0.1854 & $(0.1110)$ \\
\hline age40to54Colother & 0.0531 & $(0.1482)$ & -0.2745 & $(0.1118)$ & -0.1912 & $(0.1170)$ \\
\hline age55to64lessHSwhite & -0.5055 & $(0.1357)$ & -0.6665 & $(0.1079)$ & -0.8936 & $(0.1145)$ \\
\hline age55to64lessHSblack & -0.6226 & $(0.1487)$ & -0.8128 & $(0.1231)$ & -0.7931 & $(0.1299)$ \\
\hline age55to64lessHSother & -0.7527 & $(0.1677)$ & -0.7625 & $(0.1601)$ & -0.7394 & $(0.1445)$ \\
\hline age55to64HSwhite & -0.3706 & $(0.1334)$ & -0.5900 & $(0.0979)$ & -0.6323 & $(0.1036)$ \\
\hline age55to64HSblack & -0.4422 & $(0.1528)$ & -0.5853 & $(0.1221)$ & -0.7429 & $(0.1136)$ \\
\hline age55to64HSother & -0.2559 & $(0.1680)$ & -0.6155 & $(0.1365)$ & -0.6108 & $(0.1351)$ \\
\hline age55to64SCwhite & -0.2647 & $(0.1366)$ & -0.3870 & $(0.0984)$ & -0.4488 & $(0.1047)$ \\
\hline age55to64SCblack & -0.1017 & $(0.1624)$ & -0.3880 & $(0.1363)$ & -0.4772 & $(0.1181)$ \\
\hline age55to64SCother & -0.2622 & $(0.1838)$ & -0.2828 & $(0.1853)$ & -0.6122 & $(0.1524)$ \\
\hline age55to64Colwhite & -0.0161 & $(0.1404)$ & -0.1893 & $(0.1016)$ & -0.1638 & $(0.1045)$ \\
\hline age55to64Colblack & -0.3783 & $(0.2900)$ & 0.0139 & $(0.1473)$ & -0.2094 & $(0.1453)$ \\
\hline Constant & 5.8969 & $(0.1348)$ & 6.2695 & $(0.1077)$ & 6.4409 & $(0.1065)$ \\
\hline Observations & 26993 & & 21053 & & 21908 & \\
\hline
\end{tabular}

Standard errors in parentheses 
Table A-3

Wage Coefficients and Model Employment Predictions for Alternative Models

\begin{tabular}{|c|c|c|c|c|c|c|}
\hline & \multicolumn{3}{|c|}{ Men } & \multicolumn{3}{|c|}{ Women } \\
\hline & \multirow{2}{*}{$\begin{array}{c}\text { Wage } \\
\text { Coefficient }\end{array}$} & \multicolumn{2}{|c|}{$\begin{array}{c}\text { Predicted } \\
\text { Employment Change }\end{array}$} & \multirow{2}{*}{$\begin{array}{l}\text { Wage } \\
\text { Coefficient }\end{array}$} & \multicolumn{2}{|c|}{$\begin{array}{c}\text { Predicted } \\
\text { Employment Change }\end{array}$} \\
\hline & & $\begin{array}{l}1989- \\
1999 \\
\end{array}$ & $\begin{array}{l}1999- \\
2007 \\
\end{array}$ & & $\begin{array}{l}1989- \\
1999 \\
\end{array}$ & $\begin{array}{l}1999- \\
2007 \\
\end{array}$ \\
\hline $\begin{array}{l}\text { No Wage Selection } \\
\text { Adjustment }\end{array}$ & $\begin{array}{l}-.116 \\
(.025)\end{array}$ & -.007 & -.008 & $\begin{array}{l}.051 \\
(.017)\end{array}$ & .028 & .003 \\
\hline $\begin{array}{l}\text { Weeks-Worked-Based } \\
\text { Wage Imputation }\end{array}$ & $\begin{array}{c}.762 \\
(.015)\end{array}$ & .047 & .002 & $\begin{array}{l}.639 \\
(.009)\end{array}$ & .077 & .051 \\
\hline $\begin{array}{l}\text { Full Time Full Year } \\
\text { Weekly Wages }\end{array}$ & $\begin{array}{l}.019 \\
(.005)\end{array}$ & -.011 & -.004 & $\begin{array}{l}.030 \\
(.022)\end{array}$ & .021 & -.002 \\
\hline Hourly Wages & $\begin{array}{l}.056 \\
(.008)\end{array}$ & -.017 & -.011 & $\begin{array}{l}-.069 \\
(.036)\end{array}$ & .025 & -.004 \\
\hline $\begin{array}{l}\text { Probit for employment } \\
\text { equations }\end{array}$ & $\begin{array}{c}.175 \\
(.024) \\
(.063)\end{array}$ & -.015 & -.013 & $\begin{array}{c}.025 \\
(.042) \\
(.009)\end{array}$ & .023 & .000 \\
\hline
\end{tabular}

Notes:

Standard errors in parentheses

Probit marginal effects shown in second parentheses 


\section{References}

Aaronson, S.; B. Fallick; A. Figura; J. Pingle; and W. Wascher. 2009. “The Recent Decline in the Labor Force Participation Rate and Its Implications for Potential Labor Supply.” Brookings Papers on Economic Activity 2006 (1): 69-134.

Acemoglu, D. and D. Autor. 2011. "Skills, Tasks, and Technologies: Implications for Employment and Earnings.” In Handbook of Labor Economics, Vol. 4B, eds. O. Ashenfelter and D. Card. Amsterdam and New York: Elsevier.

Aguiar, M. and E. Hurst. 2007. "Measuring Trends in Leisure: The Allocation of Time Over Five Decades.” Quarterly Journal of Economics 122 (August): 969-1006.

Aguiar, M.; E. Hurst; and L. Karabarbounis. 2011. “Time Use During Recessions.” Working Paper 17259. Cambridge: National Bureau of Economic Research.

Antecol, H. 2010. “The Opt-Out Revolution: Recent Trends in Female Labor Supply.” Working Paper. Claremont, California: Claremont McKenna College.

Autor, D. 2010. “The Polarization of Job Opportunities in the U.S. Labor Market.” Washington: Center for American Progress and the Hamilton Project.

Autor, D.. and M.. Duggan. 2000. "The Rise in Disability Rolls and the Decline in Unemployment.” Quarterly Journal of Economics 118 (February): 157-205.

Ben-Shalom, Y.; R. Moffitt; and J.K. Scholz. Forthcoming. "An Assessment of the Effect of Anti-Poverty Programs in the United States.” Oxford Handbook of the Economics of Poverty.

Bishop, K.; B. Heim; and K. Mihaly. 2009. “Single Women’s Labor Supply Elasticities: Trends and Policy Implications.” Industrial and Labor Relations Review 63 (October): 146-168.

Blau, F. and L. Kahn. 2007. “Changes in the Labor Supply of Married Women: 1980-2000.” Journal of Labor Economics 25 (July): 393-438.

Blundell, R. and T. MaCurdy. 1999. "Labor Supply: A Review of Alternative Approaches" ” In Handbook of Labor Economics, Vol. 3A, eds. O. Ashenfelter and D. Card. Amsterdam and New York: Elsevier. 
Bound, J.; S. Lindner; and T. Waidmann. 2010. "Reconciling Findings on the Employment Effect of Disability Insurance.” Michigan Retirement Research Center WP 2010-239.

Bousey, H. 2008. “ 'Opting Out?' The Effect of Children on Women's Employment in the United States.” Feminist Economics 14 (January): 1-36.

Browning, M.; A. Deaton; and M. Irish. 1985. "A Profitable Approach to Labor Supply and Commodity Demands Over the Life Cycle.” Econometrica 53 (May): 503-43.

Feldstein, M. 1995. "The Effect of Marginal Tax Rates on Taxable Income: A Panel Study of the 1986 Tax ReformAct." Journal of Political Economy 103 (June): 551-572.

French, E. and J. B. Jones. 2011. "The Effects of Health Insurance and Self-Insurance on Retirement Behavior.” Econometrica 79 (May): 693-732.

Goldin, C. 2006. “The Quiet Revolution that Transformed Women’s Employment, Education, and Family.” American Economic Review 996 (May): 1-21.

Grogger, J. and L. Karoly. 2005. Welfare Reform: Effects of a Decade of Change. Cambridge: Harvard University Press.

Gruber, J. 2003. "Medicaid.” In Means-Tested Transfer Programs in the United States, ed. R. Moffitt. Chicago: University of Chicago Press.

Ham, J. and L. Shore-Sheppard. 2005. "Did Expanding Medicaid Affect Welfare Participation?” Industrial and Labor Relations Review 58 (April): 452-470.

Heckman, J. 1974. “Shadow Prices, Market Wages, and Labor Supply.” Econometrica 42 (July): 679-94.

Heckman, J. 1979. “Sample Selection Bias as a Specification Error.” Econometrica 47 (January): 153-61.

Heim, B. 2007. "The Incredible Shrinking Elasticities: Married Female Labor Supply, 19782002.” Journal of Human Resources 42 (Fall): 881-918.

Hotchkiss, J. 2006. "Changes in Behavioral and Characteristic Determination of Female Labor Force Participation, 1975-2005.” Federal Reserve Bank of Atlanta Economic Review 91(2): 1-20.

Jacob, B. and J. Ludwig. 2012. "The Effects of Housing Assistance on Labor Supply: Evidence from a Voucher Lottery.” American Economic Review 102 (February): 272-304.

Juhn, C. 1992. "Decline of Male Labor Market Participation: The Role of Declining Market Opportunities.” Quarterly Journal of Economics 107 (February): 79-121. 
Juhn, C.; K. Murphy; and R. Topel. 1991. "Why Has the Natural Rate of Unemployment Increased over Time.” Brookings Papers on Economic Activity 2: 75-126.

Katz, L. and D. Autor. 1999. “Changes in the Wage Structure and Earnings Inequality.” In Handbook of Labor Economics, Vol. 3A, eds. O. Ashenfelter and D. Card. Amsterdam and New York: Elsevier.

Keane, M. 2011. “Labor Supply and Taxes: A Survey.” Journal of Economic Literature 49 (December): 961-1075.

Keane, M. and R. Rogerson. 2012. "Micro and Macro Labor Supply Elasticities: A Reassessment of Conventional Wisdom.” Journal of Economic Literature 50 (June): 464-476.

Killingsworth, M. 1983. Labor Supply. Cambridge: Cambridge University Press.

Klerman, J. and C. Danielson. 2009. “Determinants of the Food Stamp Program Caseload.” http://hdl.handle.net/10113/32849 .

Leftin, J. and K. Wolkwitz. 2009. Trends in Supplemental Nutrition Assistance Program Participation Rates: 2000 to 2007. Washington: Food and Nutrition Service, U.S. Department of Agriculture.

Macunovich, D. 2010. "Reversals in the Patterns of Women’s Labor Supply in the United States, 1977-2009.” Monthly Labor Review 133 (November): 16-36.

Meghir, C. and D. Phillips. 2010. "Labour Supply and Taxes.” In Dimensions of Tax Design, eds. Stuart Adam et al. Oxford: Oxford University Press.

Moffitt, R. 1992. “The Incentive Effects of the U.S. Welfare System: A Review.” Journal of Economic Literature 30 (March): 1-61.

Moffitt, R. 1993. "Identification and Estimation of Dynamic Models with a Time Series of Repeated Cross Sections.” Journal of Econometrics 59 (September): 99-123.

Moffitt, R. and M. Wilhelm. 2000. "Taxation and the Labor Supply Decisions of the Affluent.” In Does Atlas Shrug? Economic Consequences of Taxing the Rich, ed. J. Slemrod. Cambridge: Harvard University Press.

Mroz, T. 1987. “The Sensitivity of an Empirical Model of Married Women’s Hours of Work to Economic and Statistical Assumptions.” Econometrica 55 (July): 765-99.

Ramey, G. and V. Ramey. 2010. “The Rug Rat Race.” Brookings Papers on Economic Activity 2 (Spring): 129-76.

Raphael, Steven. 2010. "Understanding the Causes and Labor Market Consequences of the Steep Increase in U.S. Incarceration Rates.” In Labor in the Era of Globalization, eds. Clair 
Brown, Barry Eichengreen, and Michael Reich. New York: Cambridge University Press.

Rogerson, R. and J. Wallenius. 2009. "Micro and Macro Elasticities in a Life Cycle Model with Taxes.” Journal of Economic Theory 144 (November): 2277-92.

Romer, Christina D. and David H. Romer. 2012. “The Incentive Effects of Marginal Tax Rates.” Working Paper 17860. Cambridge: National Bureau of Economic Research.

Saez, E.; J. Slemrod; and S. Giertz. 20. “The Elasticity of Taxable Income With Respect to Marginal Tax Rates: A Critical Review.” Journal of Economic Literature 50 (March): 350 .

Salomon, J.; S. Nordhagen; S. Oza; and C. Murray. 2009. “Are Americans Feeling Less Health? the Puzzle of Trends in Self-Rated Health.” American Journal of Eipdemiology 170(3): 343-351.

Shimer, R. 2011. “Job Search, Labor Force Participation, and Wage Rigidities.” Working Paper, University of Chicago.

Stock, J. and M. Watson. 2012. "Disentangling the Channels of the 2007-2009 Recession.” Brookings Papers on Economic Activity. Spring.

U.S. Congressional Budget Office. “The Budget and Economic Outlook: Fiscal Years 2012 to 2022.” http://www.cbo.gov/publication/42905. Accessed 10/10/2012.

U.S. Department of Agriculture. 2001. Characteristics of Food Stamp Households: Fiscal Year 2000. Washington: Food and Nutrition Service.

U.S. Department of Agriculture. 2008. Characteristics of Food Stamp Households: Fiscal Year 2007. Washington: Food and Nutrition Service.

Ventura, S. 2009. “Changing Patterns of Nonmarital Childbearing in the United States.” NCHS Data Brief 18. Washington: Centers for Disease Control and Prevention, U.S. Department of Health and Human Services.

Von Wachter, T.; J. Manchester; and J. Song. 2011. “Trends in Employment and Earnings of Allowed and Rejected Applicants to the Social Security Disability Insurance Program.” American Economic Review 101 (December): 3308-2

Walls, C. et al. 2010. “The Case for Staying Home.” Time March 24, 2004. On the internet at www.time.com/time/magazine/article/0,9171,993641,00.html (visited August 5, 2012). 
Figure 1: Employment to Population Ratio, 1970-2011 U.S. Civilian Noninstitutional Population ages 16-64

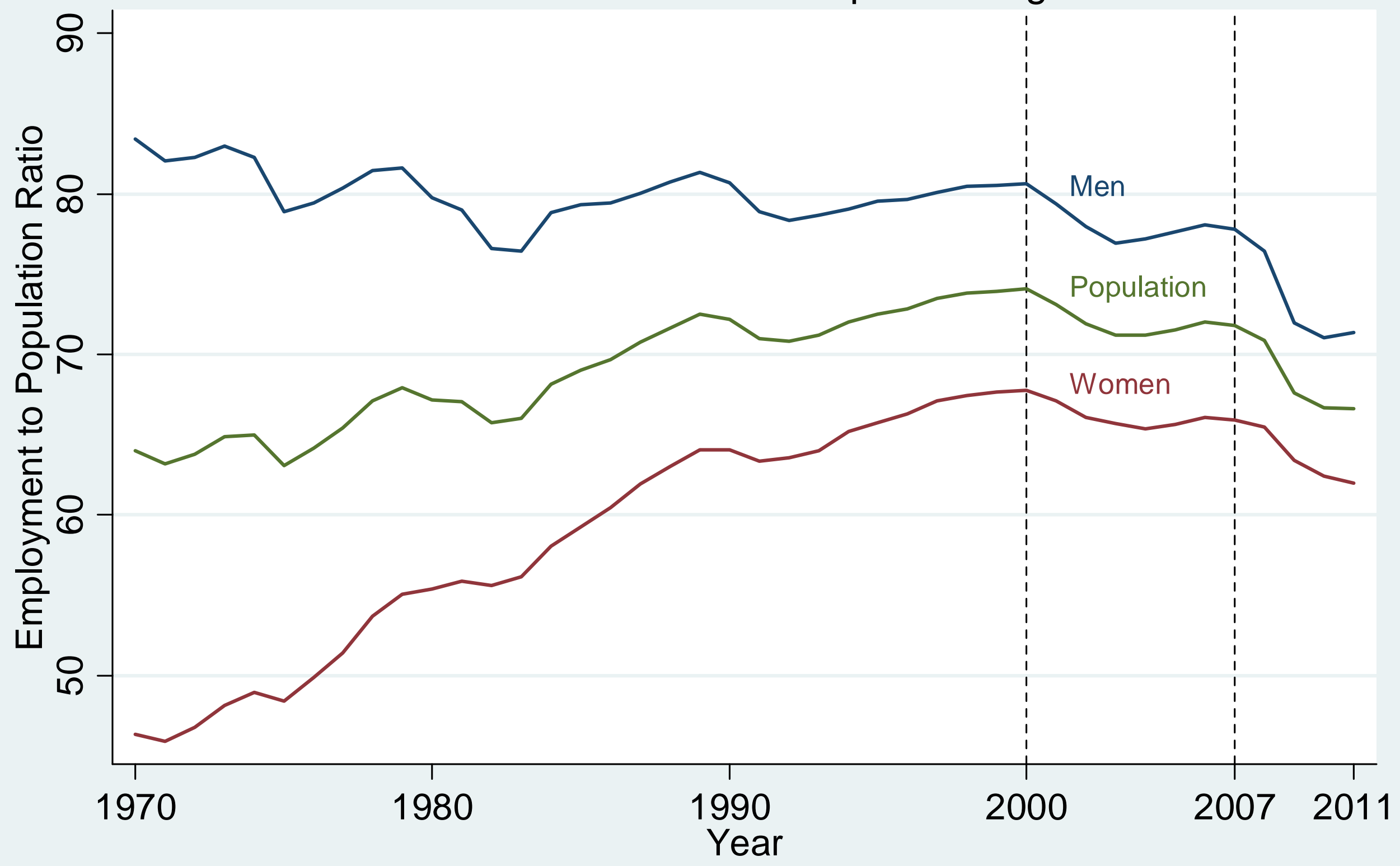


Figure 2: Employment-Population Ratio and National Unemployment Rate

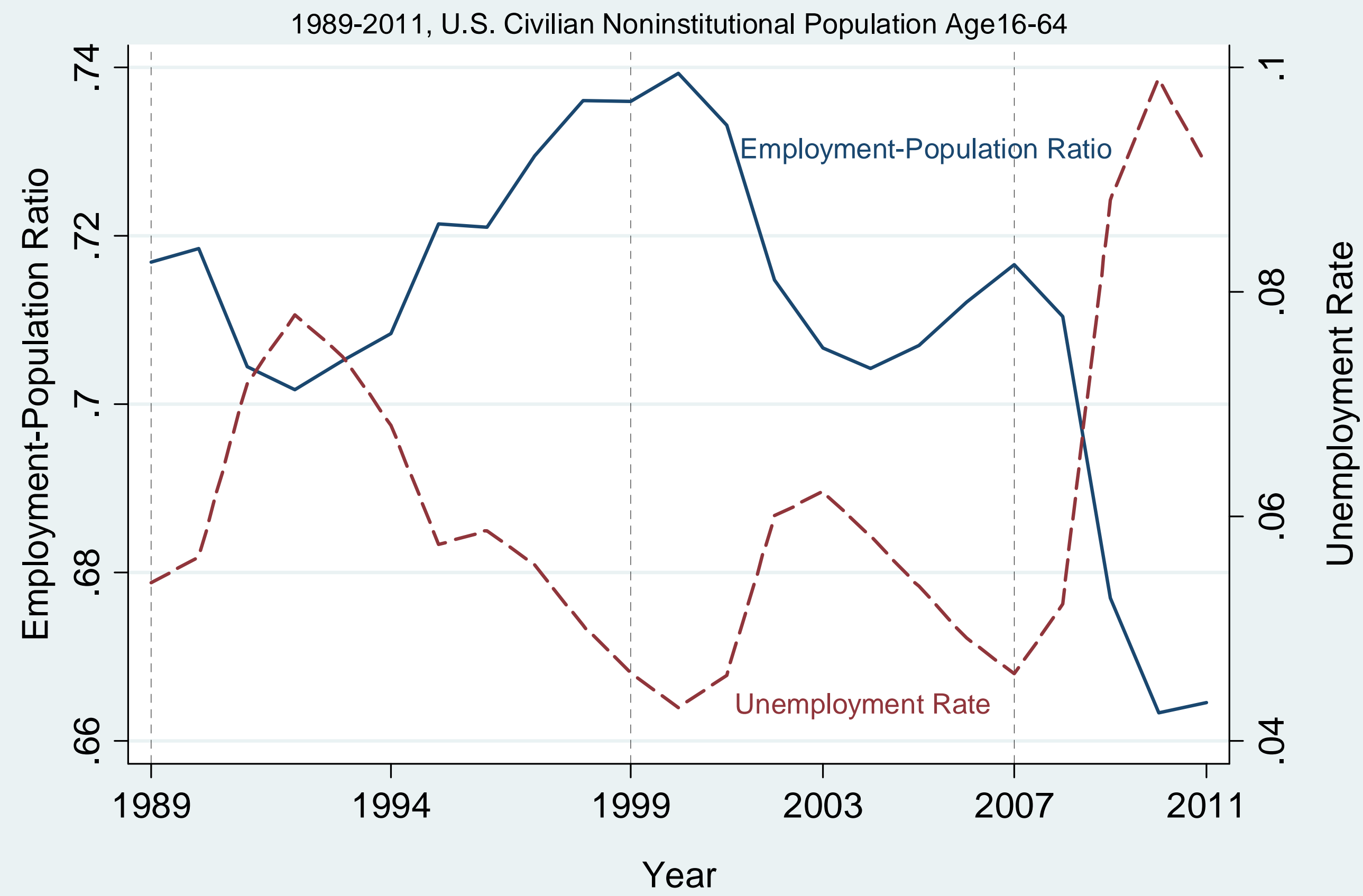


Figure 3: Actual and Hypothetical Employment-Population Ratio 1989-2011, Fixed 1999 Demographic Composition

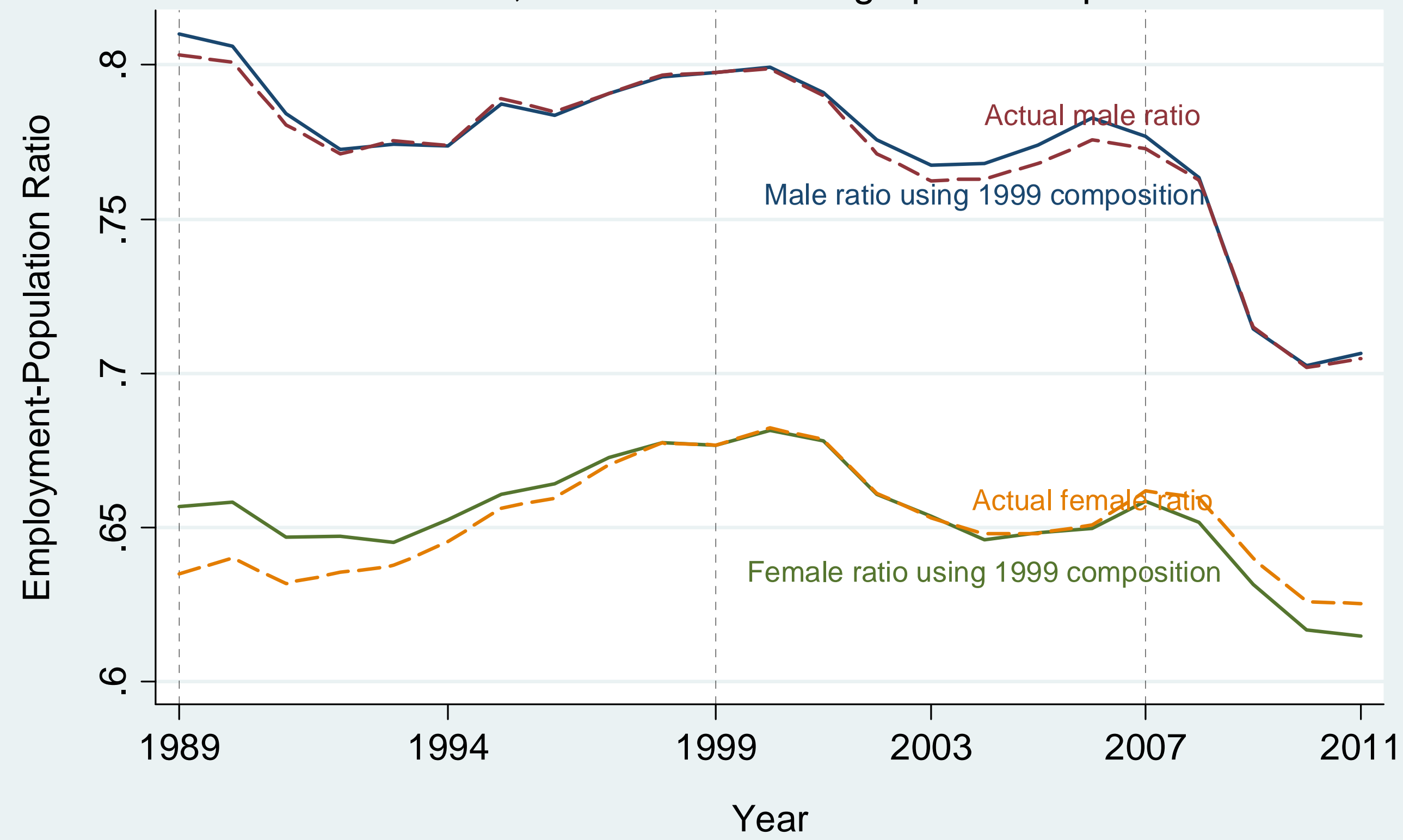

Fixed-Composition calculated by fixing 1999 age, gender, education, and race proportions 


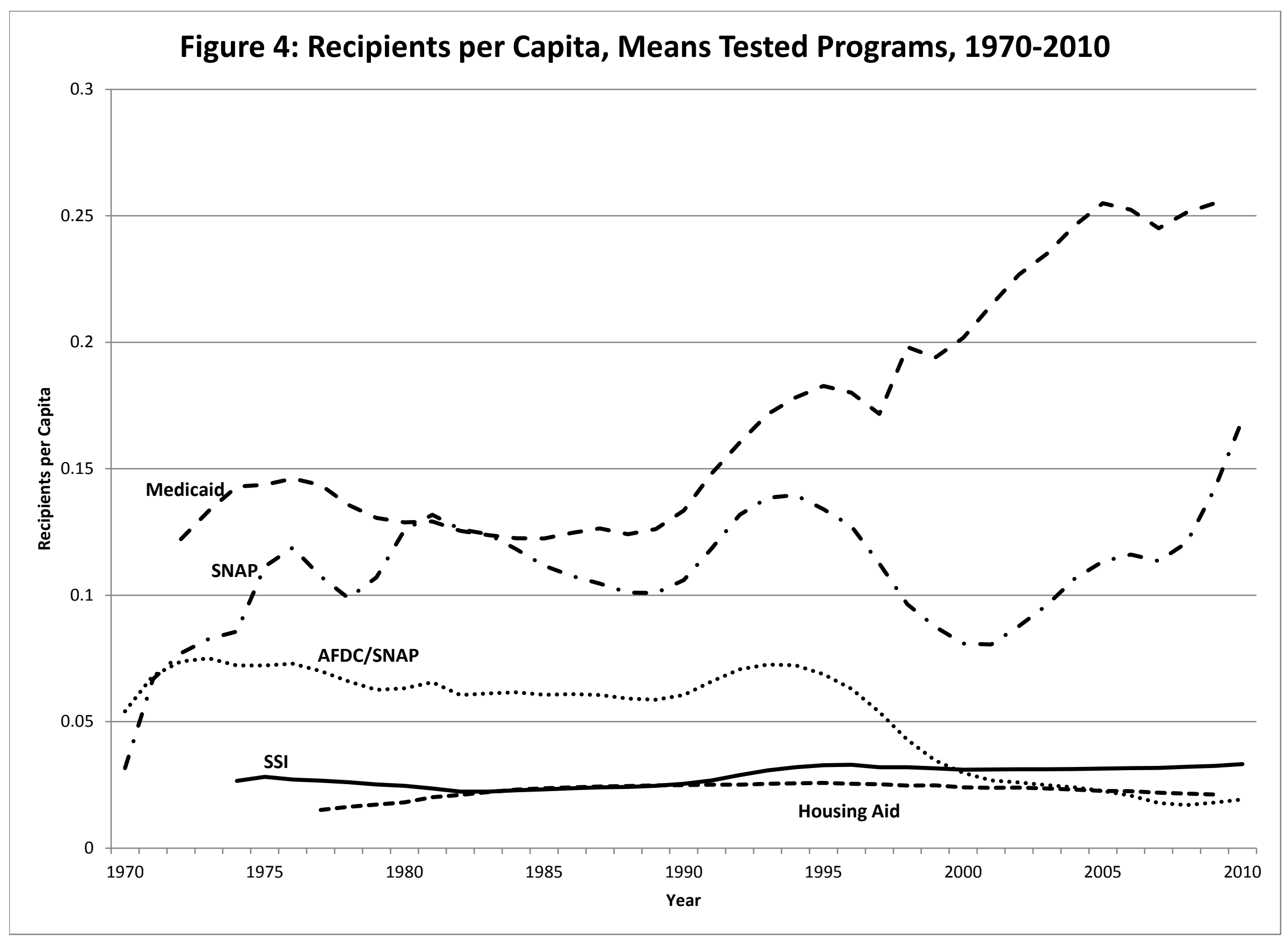


Figure 5: Recipients per Capita, Unemployment and Disability Insurance, 1970-2010

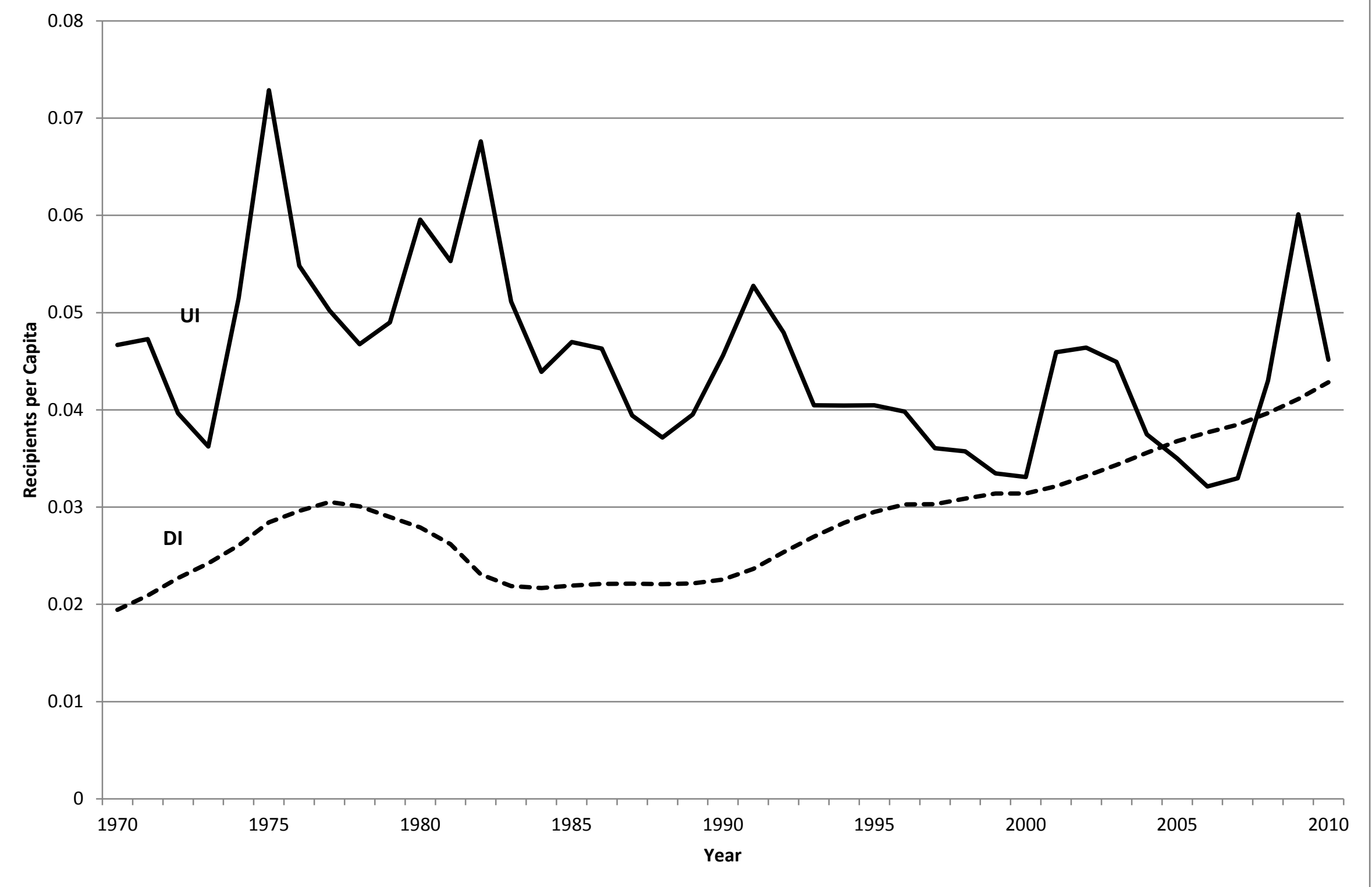


Table 1(a)

Changes in the Male Employment-Population Ratio, 1999-2007 and 1989-1999, by Age and Education

\begin{tabular}{ccccc}
\hline Age & \multicolumn{4}{c}{ Education } \\
\cline { 2 - 5 } & Less than HS & HS Graduate & Some College & College or More \\
\hline $1999-2007$ & -.079 & -.041 & -.009 & -.037 \\
$25-39$ & -.004 & -.036 & -.023 & .010 \\
$40-54$ & -.037 & -.026 & -.007 & -.002 \\
$55-64$ & -.016 & -.036 & -.023 & .005 \\
$1989-1999$ & & & & \\
$16-24$ & -.037 & -.014 & -.015 & .031 \\
$25-39$ & .012 & .005 & -.007 & -.011 \\
$40-54$ & -.026 & -.032 & -.038 & -.012 \\
$55-64$ & -.021 & -.023 & .005 & .017 \\
\hline
\end{tabular}

Table 1(b)

Changes in the Female Employment-Population Ratio, 1999-2007 and 1989-1999, by Age and Education

\begin{tabular}{ccccc}
\hline Age & \multicolumn{4}{c}{ Education } \\
\cline { 2 - 5 } & Less than HS & HS Graduate & Some College & College or More \\
\hline $1999-2007$ & -.077 & -.074 & -.018 & -.043 \\
$25-39$ & -.057 & -.042 & -.019 & -.030 \\
$40-54$ & .016 & -.004 & -.018 & -.019 \\
$55-64$ & .032 & .029 & .042 & .070 \\
$1989-1999$ & & & & \\
$16-24$ & .010 & .041 & -.015 & -.000 \\
$25-39$ & .071 & .022 & .024 & -.001 \\
$40-54$ & .010 & .012 & .019 & .027 \\
$55-64$ & .006 & .044 & .038 & .025 \\
\hline
\end{tabular}

Note: This and all CPS figures in this paper are weighted using the CPS Basic Weight. 
Table 2

Changes in Rates of School Attendance by Gender and Completed Education, 16-24 Age Group, 1999-2007 and 1989-1999

\begin{tabular}{lcc}
\hline Education & $1999-2007$ & $1989-1999$ \\
\hline$\underline{\text { Men }}$ Less than HS & .009 & .047 \\
HS Graduate & .015 & -.055 \\
Some College & -.010 & -.013 \\
College or more & -.003 & .021 \\
Women & .036 & .059 \\
Less than HS & .046 & -.029 \\
HS Graduate & .018 & .055 \\
Some College & .060 & .033 \\
College or More & & \\
\hline
\end{tabular}


Table 3(a)

Changes in the Male Employment-Population Ratio, by Marital Status, Age and Education, 1999-2007

\begin{tabular}{ccccc}
\hline Age & \multicolumn{4}{c}{ Education } \\
\cline { 2 - 5 } & Less than HS & HS Graduate & Some College & College or More \\
\hline Married & & & & \\
$16-24$ & -.068 & -.039 & -.034 & -.128 \\
$25-39$ & .006 & -.019 & -.002 & -.002 \\
$40-54$ & -.023 & -.010 & -.010 & .001 \\
$55-64$ & -.009 & -.033 & -.020 & -.004 \\
Unmarried & & & & \\
$16-24$ & -.073 & -.035 & -.002 & -.021 \\
$25-39$ & -.015 & -.047 & -.042 & .027 \\
$40-54$ & -.046 & -.046 & .005 & -.006 \\
$55-64$ & -.006 & -.022 & -.007 & .067 \\
\hline
\end{tabular}

Table 3(b)

Changes in the Female Employment-Population Ratio, by Marital Status, Age and Education,1999-2007

\begin{tabular}{ccccc}
\hline Age & \multicolumn{4}{c}{ Education } \\
\cline { 2 - 5 } Married & Less than HS & HS Graduate & Some College & College or More \\
\hline $16-24$ & -.046 & -.111 & .010 & -.009 \\
$25-39$ & -.061 & -.044 & .006 & -.029 \\
$40-54$ & .036 & .010 & -.013 & -.019 \\
$55-64$ & .048 & .011 & .033 & .077 \\
Unmarried & & & & \\
$16-24$ & -.079 & -.069 & -.021 & -.052 \\
$25-39$ & -.047 & -.050 & -.060 & -.023 \\
$40-54$ & -.014 & -.034 & -.026 & -.018 \\
$55-64$ & .014 & .062 & .060 & .053 \\
\hline
\end{tabular}


Table 4(a)

Changes in the Male Real Log Weekly Wage, 1999-2007 and 1989-1999, by Age and Education

\begin{tabular}{ccccc}
\hline Age & \multicolumn{5}{c}{ Education } \\
\cline { 2 - 5 } & Less than HS & HS Graduate & Some College & College or More \\
\hline $1999-2007$ & -.014 & -.027 & .007 & -.036 \\
$16-24$ & .003 & -.028 & -.037 & .018 \\
$40-54$ & -.035 & -.018 & .003 & .075 \\
$55-64$ & -.030 & -.010 & -.018 & .004 \\
$1989-1999$ & & & & \\
$16-24$ & .117 & .076 & .031 & .188 \\
$25-39$ & .003 & .023 & .027 & .137 \\
$40-54$ & -.004 & -.031 & -.004 & .101 \\
$55-64$ & -.039 & .016 & -.019 & .138 \\
\hline
\end{tabular}

Table 4(b)

Changes in the Female Real Log Weekly Wage, 1999-2007 and 1989-1999, by Age and Education

\begin{tabular}{ccccc}
\hline \multirow{2}{*}{ Age } & \multicolumn{4}{c}{ Education } \\
\cline { 2 - 5 } & Less than HS & HS Graduate & Some College & College or More \\
\hline $1999-2007$ & & & & \\
$16-24$ & -.111 & .033 & -.008 & .036 \\
$25-39$ & .038 & .028 & .071 & .043 \\
$40-54$ & .049 & .047 & .048 & .088 \\
$55-64$ & -.105 & .117 & .022 & .160 \\
$1989-1999$ & & & & \\
$16-24$ & .174 & .095 & -.009 & .075 \\
$25-39$ & .099 & .100 & .050 & .144 \\
$40-54$ & .099 & .095 & .119 & .160 \\
$55-64$ & .217 & .100 & .238 & .264 \\
\hline
\end{tabular}


Table 5

Selected Estimated OLS Coefficients for Employment Regressions, Pooled 1989, 1999, 2007 Observations

\begin{tabular}{lcc}
\hline & Men & Women \\
\hline Log Real Weekly Wage & $.060^{*}$ & .009 \\
Weekly Nonlabor Income/1000 & $(.008)$ & $(.015)$ \\
& $-.001^{*}$ & $-.001^{*}$ \\
No. Own Children 0-5 & $(.000)$ & $(.000)$ \\
& .000 & $-.120^{*}$ \\
No. Own Children 6-18 & $(.002)$ & $(.003)$ \\
Married & $.006^{*}$ & $-.027^{*}$ \\
& $(.001)$ & $(.002)$ \\
Divorced, Widowed, or & $.072^{*}$ & $-.042^{*}$ \\
Separated ${ }^{1}$ & $(.005)$ & $(.005)$ \\
Head of Household & $.019 *$ & .004 \\
Unmarried Parent & $(.006)$ & $(.005)$ \\
& $.079^{*}$ & $.096^{*}$ \\
& $(.006)$ & $(.005)$ \\
Notes: Standard errors & $.025^{*}$ & $(.006)$ \\
\hline
\end{tabular}

Notes: Standard errors in parentheses. *: significant at the 10 percent level. Equations contain a full set of age-education-race interactions.

${ }^{1}$ The omitted marital-status category is Single. 
Table 6

Actual and Predicted Changes in Employment-Population Ratio, by Gender, Time Period, and Model

\begin{tabular}{lccccc}
\hline & \multicolumn{2}{c}{$1989-1999$} & & \multicolumn{2}{c}{$1999-2007$} \\
\cline { 2 - 3 } Men & Actual & Predicted & & Actual & Predicted \\
Women & -.006 & -.017 & & -.025 & -.013 \\
& .042 & .023 & & -.015 & .001 \\
\hline
\end{tabular}


Table 7

Changes in Mean Determinants of Employment-Population Ratio, by Gender and Time Period

\begin{tabular}{|c|c|c|}
\hline & 1989-1999 & 1999-2007 \\
\hline \multicolumn{3}{|l|}{$\underline{\text { Men }}$} \\
\hline Log Real Weekly Wage & -.028 & -.101 \\
\hline $\begin{array}{l}\text { Log Weekly Nonlabor } \\
\text { Income/1000 }\end{array}$ & .585 & -.241 \\
\hline No. Own Children 0-5 & -.031 & -.008 \\
\hline No. Own Children 6-18 & .004 & -.027 \\
\hline Married & -.028 & -.014 \\
\hline $\begin{array}{l}\text { Divorced, Widowed, or } \\
\text { Separated }\end{array}$ & .016 & -.002 \\
\hline Head of Household & -.014 & -.006 \\
\hline Unmarried Parent & .007 & -.000 \\
\hline \multicolumn{3}{|l|}{$\underline{\text { Women }}$} \\
\hline Log Real Weekly Wage & .223 & .072 \\
\hline $\begin{array}{l}\text { Log Weekly Nonlabor } \\
\text { Income/1000 }\end{array}$ & .549 & -.203 \\
\hline No. Own Children 0-5 & -.034 & -.007 \\
\hline No. Own Children 6-18 & .008 & -.026 \\
\hline Married & -.031 & -.012 \\
\hline $\begin{array}{l}\text { Divorced, Widowed, or } \\
\text { Separated }\end{array}$ & .008 & -.003 \\
\hline Head of Household & -.012 & -.007 \\
\hline Unmarried Parent & .006 & -.001 \\
\hline
\end{tabular}


Table 8

Predicted Changes in the Male Employment-Population Ratio, 1999-2007, by Age and Education

\begin{tabular}{ccccc}
\hline \multirow{2}{*}{ Age } & \multicolumn{4}{c}{ Education } \\
\cline { 2 - 5 } Men & Less than HS & HS Graduate & Some College & College or More \\
\hline $16-24$ & -.009 & -.020 & -.013 & -.017 \\
$25-39$ & -.007 & -.019 & -.014 & -.004 \\
$40-54$ & -.015 & -.014 & -.006 & -.001 \\
$55-64$ & -.018 & -.006 & -.007 & -.003 \\
$\frac{\text { Women }}{16-24}$ & .003 & -.006 & .003 & .000 \\
$25-39$ & -.010 & -.006 & -.004 & -.014 \\
$40-54$ & .001 & -.002 & .002 & -.003 \\
$55-64$ & -.003 & .003 & -.002 & .004 \\
\hline
\end{tabular}


Table 9

Wage Coefficients and Actual and Predicted Changes in Employment-Population Ratio of Women by Time Period, Marital Status, and Presence of Children

\begin{tabular}{|c|c|c|c|c|c|}
\hline & \multirow{2}{*}{$\begin{array}{c}\text { Wage } \\
\text { Coefficient }\end{array}$} & \multicolumn{2}{|c|}{ 1989-1999 } & \multicolumn{2}{|c|}{ 1999-2007 } \\
\hline & & Actual & Predicted & Actual & Predicted \\
\hline Married & $\begin{array}{c}.076 \\
(.016)\end{array}$ & .052 & .045 & -.003 & -.011 \\
\hline Unmarried & $\begin{array}{l}-.077 \\
(.012)\end{array}$ & .028 & .034 & -.029 & -.030 \\
\hline Children & $\begin{array}{l}.045 \\
(.046)\end{array}$ & .126 & .034 & -.003 & .020 \\
\hline No Children & $\begin{array}{c}.066 \\
(.008)\end{array}$ & -.001 & -.011 & -.035 & -.027 \\
\hline
\end{tabular}

Notes:

Standard errors in parentheses 
Table 10

Average Tax Rates in the Federal Income Tax, 2000-2007

\begin{tabular}{lccccc}
\hline & & \multicolumn{5}{c}{ Adjusted Gross Income } \\
\cline { 3 - 6 } & Returns & $\$ 1-$ & $\$ 30,000-$ & $\$ 50,000-$ & $\$ 100,000-$ \\
& & $\$ 10,000$ & $\$ 50,000$ & $\$ 100,000$ & $\$ 200,000$ \\
\hline 2000 & 16.1 & 4.5 & 9.4 & 12.2 & 17.3 \\
2001 & 15.2 & 2.8 & 9.1 & 11.7 & 16.6 \\
2002 & 14.1 & 2.5 & 8.0 & 10.6 & 158. \\
2003 & 13.0 & 2.5 & 7.6 & 9.6 & 14.0 \\
2004 & 13.3 & 2.4 & 7.6 & 9.2 & 13.6 \\
2005 & 13.6 & 2.5 & 7.5 & 9.1 & 13.3 \\
2006 & 13.8 & 2.7 & 7.4 & 9.0 & 13.1 \\
2007 & 13.8 & 2.7 & 7.3 & 9.0 & 12.8 \\
\hline
\end{tabular}

Source: SOI Bulletin, Selected Issues. Nominal dollars. 
Table 11

Changes in the Fraction Receiving Disability Income, 1999-2007, by Age, Education, and Gender

\begin{tabular}{ccccc}
\hline Age & \multicolumn{4}{c}{ Education } \\
\cline { 2 - 5 } Men & Less than HS & HS Graduate & Some College & College or More \\
\hline $16-24$ & .0004 & .0019 & -.0003 & .0000 \\
$25-39$ & -.0018 & -.0009 & -.0007 & -.0008 \\
$40-54$ & -.0014 & .0033 & -.0006 & .0008 \\
$55-64$ & .0041 & -.0021 & .0070 & -.0062 \\
$\frac{\text { Women }}{16-24}$ & .0006 & .0017 & -.0008 & .0000 \\
$25-39$ & -.0006 & -.0017 & .0001 & -.0024 \\
$40-54$ & .0028 & .0009 & .0017 & .0011 \\
$55-64$ & .0022 & .0059 & .0011 & .0014 \\
\hline
\end{tabular}




\section{Table 12}

SNAP Households by Poverty Status as a Percent of the Poverty Line (percentage distribution)

Gross Income as a Percent of the Poverty Line

$0-25 \%$

$26 \%-50 \%$

$51 \%-75 \%$

$76 \%-100 \%$

$101 \%-130 \%$

$131 \%$ and over

Total
16.8

16.2

25.3

30.3

10.4

1.0

100.0
23.6

15.3

17.8

30.7

10.5

2.1

100.0

Sources: U.S. Department of Agriculture (2001), U.S. Department of Agriculture (2008). 